\title{
Smallest Late Pleistocene inhabited island in Australasia reveals the impact of post-glacial sea-level rise on human behaviour from 17,000 years ago
}

\author{
Ben Shaw ${ }^{\text {a, b, * , Simon Coxe }}{ }^{c}$, Jemina Haro ${ }^{d}$, Karen Privat ${ }^{\text {a, e }}$, Simon Haberle ${ }^{b}$, \\ Felicitas Hopf ${ }^{b}$, Emily Hull ${ }^{\text {a }}$, Stuart Hawkins ${ }^{\mathrm{b}}$, Geraldine Jacobsen ${ }^{\mathrm{f}}$ \\ a School of Biological, Earth and Environmental Sciences, Changing Earth, University of New South Wales, Sydney, New South Wales, 2052, Australia \\ ${ }^{\mathrm{b}}$ Archaeology and Natural History Program, School of Culture, History and Language, College of Asia and the Pacific, The Australian National University, \\ Canberra, Australia \\ ${ }^{\mathrm{c}}$ Monash Indigenous Studies Centre, Monash University, Melbourne, Victoria, 3800, Australia \\ d National Museum and Art Gallery of Papua New Guinea, Port Moresby, National Capital District, Papua New Guinea \\ ${ }^{\text {e }}$ Electron Microscope Unit, Mark Wainwright Analytical Centre, University of New South Wales, Sydney, New South Wales, 2052, Australia \\ ${ }^{\mathrm{f}}$ Australian Nuclear Science and Technology Organisation, New Illawarra Road, Lucas Heights, Sydney, New South Wales, 2234, Australia
}

\section{A R T I C L E I N F O}

\section{Article history:}

Received 10 May 2020

Received in revised form

29 June 2020

Accepted 25 July 2020

Available online 16 August 2020

\section{Keywords:}

Pleistocene

Holocene

Sea-level changes

Equatorial pacific

Sahul-new Guinea

Massim

Adaptive behaviour

Island settlement

Vegetation dynamics

\begin{abstract}
A B S T R A C T
Late Pleistocene records of island settlement can shed light on how modern humans (Homo sapiens) adapted their behaviour to live on ecologically marginal landscapes. When people reached Sahul (Pleistocene New Guinea-Australia), between 65 and $50 \mathrm{ka}$, the only islands they would have encountered were in the tropical north. This unique geographic situation therefore offers the only possibility of modelling human adaptive behaviour to islands in Australasia during the Late Pleistocene. Cave excavation on the uplifted limestone island of Panaeati in the Massim region of Southeastern New Guinea revealed a cultural sequence commencing from 17,300-16,800 cal. BP, suggesting habitation of higher coastlines occurred as low-lying shorelines destabilised during the initial stages of deglacial sea-level rise. No cave use was evident between 12,400 and 4780 cal. BP when the continental shelf was fully inundated, and Panaeati reduced in size by $90 \%$. It is likely that diminished coastlines and the reduced resources of low-lying islands could no longer support pre-agricultural populations during this time. Cultural groups that were better adapted to living on small islands returned to Panaeati by 4780 -4490 cal. BP when sea levels had stabilised, lagoons formed, and coastal ecosystems had diversified. Investigations demonstrate the role of larger islands as refugia during deglacial sea-level rise and the effects on human dispersals and cultural diversity.
\end{abstract}

() 2020 Elsevier Ltd. All rights reserved.

\section{Introduction}

The dispersal of modern humans (Homo sapiens) from Eurasia to Sahul (the joint Pleistocene New Guinea-Australia landmass) between 65 and 50 ka was the first time our species migrated away from a continental landscape (Bird et al., 2019; Bradshaw et al., 2019; Clarkson et al., 2017; Summerhayes et al., 2010a; Veth et al., 2017; Will et al., 2019). Archaic human species had

\footnotetext{
* Corresponding author. School of Biological, Earth and Environmental Sciences, Changing Earth Research Centre, University of New South Wales, Sydney, New South Wales, 2052, Australia.

E-mail address: Ben.shaw@unsw.edu.au (B. Shaw).
}

occupied the Wallacean islands separating these ecologically distinct continents for at least one million years (Brumm et al., 2010; van den Bergh et al., 2016). However, on current evidence, Wallacea formed an ecological and technological barrier preventing earlier dispersals to Sahul (Hawkins et al., 2017; Kealy et al., 2016; O'Connor et al., 2017) (Fig. 1a). Once in Sahul, people would have only encountered islands in the tropical north where deep submarine trenches separate volcanic arcs from New Guinea (northern Sahul). These islands were separated from Sahul even during the Last Glacial Maximum (LGM, 23-19 ka) when sea levels were 135-125 m lower (Hanebuth et al., 2009; Ishiwa et al., 2016; Lambeck et al., 2014). No islands were present around Australian (central-southern Sahul) or southern New Guinea shores until the 


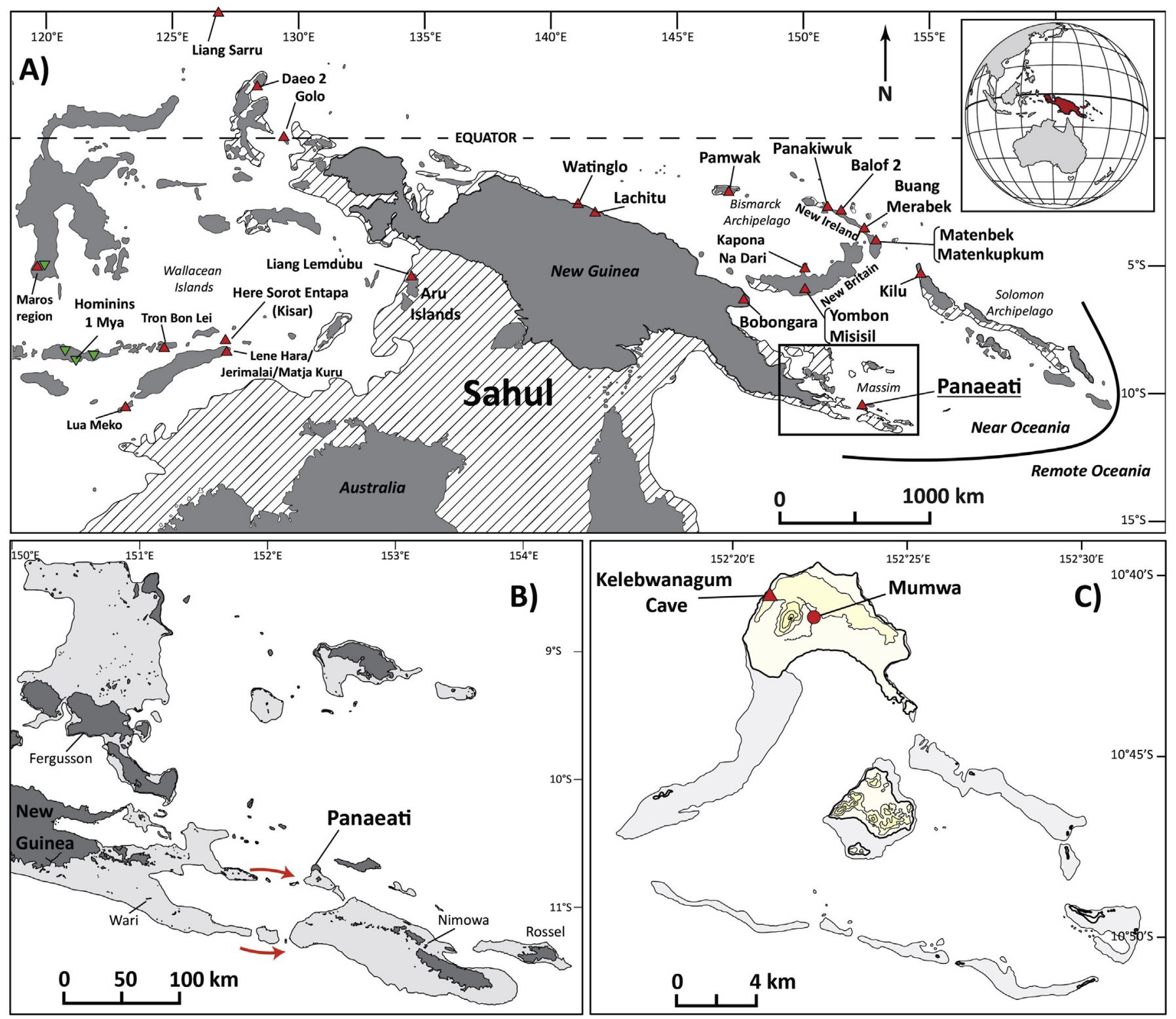

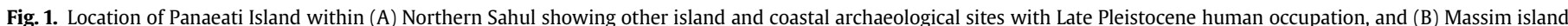

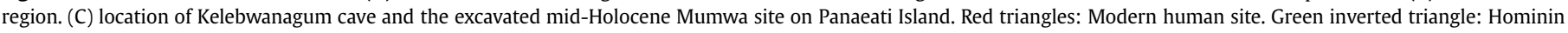

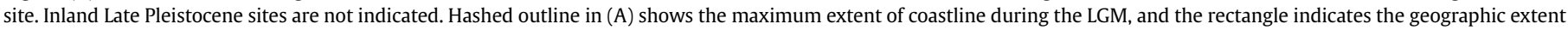

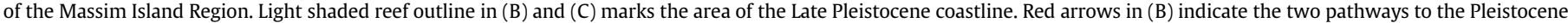

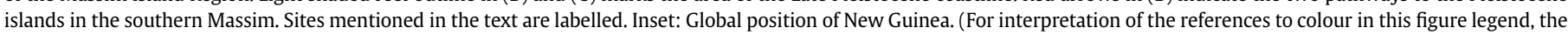
reader is referred to the Web version of this article.)

Holocene ( $\leq 11.7 \mathrm{ka}$ ) when post-glacial sea-level rise drowned the shallow continental shelf and the Late Pleistocene coastline (Beaton, 1995; McNiven et al., 2014; O'Connor et al., 2006; Rowland et al., 2015; Sim and Wallis, 2008; Ulm, 2011; Veth et al., 2017). New Guinea, therefore, presents the only opportunity to model Late Pleistocene $(\geq 11.7 \mathrm{ka})$ human behavioural adaptations to Near Oceanic island ecosystems immediately adjacent to Sahul (See Green, 1991 for Near/Remote Oceanic definition) (Fig. 1a).

The Bismarck and Solomon Archipelagoes were settled by 43.8-42.4 cal ka (Buang Merabak) and 33.1-31.4 cal ka (Kilu cave), respectively, marking the furthest extent of modern human dispersals into the Pacific region during the Late Pleistocene (Allen et al., 1988; Green, 1991; Leavesley and Allen, 1998; Wickler and Spriggs, 1988). Late Pleistocene populations lacked the technological and navigational capability needed to make the longer open sea voyages ( $\geq 350 \mathrm{~km}$ ) to Remote Oceanic archipelagoes further east (Irwin, 1992). These remote islands were only colonised around 3000 years ago by agriculturalist seafarers defined as the Lapita culture (Bedford et al., 2019; Sheppard et al., 2015; Summerhayes, 2007).

Ten cave and rockshelter sites with evidence for Late Pleistocene human habitation are known on the islands of New Britain $\left(37,050 \mathrm{~km}^{2}\right)$, New Ireland $\left(7620 \mathrm{~km}^{2}\right)$, Manus $\left(1740 \mathrm{~km}^{2}\right)$, and Buka $\left(638 \mathrm{~km}^{2}\right)$ in the Bismarck and Solomon archipelagoes. A further three sites dating from at least $42.5-36.5 \mathrm{cal}$ ka (Latchitu Cave) are also known on the north coast of New Guinea, the only part of Sahul where because of its steep bathymetry changes in sea level had not significantly altered the position of the coastline (Fig. 1a). Near 
coastal sites have been identified on the Aru Islands, to the southwest of New Guinea, dating from 27.3 to 26.7 cal ka (Liang Lemdubu) which at this time formed part of the now submerged Sahul landbridge (O'Connor et al., 2006). An extensive suite of Late Pleistocene sites are otherwise known in the interior lowlands, mountains and deserts of New Guinea and Australia (Hiscock, 2008; Smith, 2013; Summerhayes et al., 2017). Meta-analytic modelling of these records indicate that widespread human dispersals had occurred across Sahul prior to the Extended Glacial Period from $30 \mathrm{ka}$ (Bird et al., 2016; O'Connell and Allen, 2007; Williams et al., 2015).

A significant decrease in land size and endemic biota in the Bismarck and Solomon Archipelagoes relative to the vast mosaic landscapes of continental Sahul required innovative behavioural adaptations in resource use, settlement and long-distance seafaring (Fredericksen et al., 1993; Leavesley, 2006; Summerhayes et al., 2017). For the first 20 ka following colonisation relatively small and mobile groups of people exploited marine foods predominantly from fringing reefs and vertebrate fauna from the surrounding rainforest (Gosden and Robertson, 1991; Leavesley, 2004). Low-density settlement continued during significant sea-level drawdown from $30 \mathrm{ka}$, with reduced cave use or complete abandonment apparent at most sites during the LGM (Leavesley, 2006). Behavioural adaptations during the LGM reinforced foodways and social networks, which included the introduction of cuscus (Phalanger orientalis) as a protein resource in a depauperate terrestrial ecosystem, and the commencement of inter-island obsidian trade across distances over $200 \mathrm{~km}$ (Allen and Gosden, 1996; Summerhayes and Allen, 1993). Landscape use increased over subsequent millennia and intensified throughout the
Holocene (Fig. 2, Fig. S1).

Islands in the Massim region of southeastern Papua New Guinea, unlike the Bismarck Archipelago, the north coast of New Guinea, and Wallacea, reduced significantly in size and changed configuration following the LGM. These changes greatly affected ecosystem biodiversity and proximity to the Sahul supercontinent (Fig. 1b). The extensive reef systems encompassing many of the southern Massim islands mark the former position of the Pleistocene coastline which lie on a shallow continental plate $30-90 \mathrm{~m}$ below current sea levels (Lambeck et al., 2014; Shaw, 2016b). Robust waisted blades, a technological tool innovation known across Sahul from at least $50 \mathrm{ka}$, have been found in undated surface contexts on the easternmost Massim island of Rossel (Allen and O'Connell, 2014; Bulmer, 1977; Clarkson et al., 2017; Groube et al., 1986; Lampert, 1981, 1983; Shaw, 2017). Rossel is inhabited by a linguistically unique population, possibly with distant connections to the Solomon Islands, suggesting long-term isolation since the Late Pleistocene (Dunn et al., 2008; Shaw, 2015). Genetic evidence further suggests increased diversification of mitochondrial lineages in Massim and other Near Oceanic island populations during and immediately after the LGM (Pedro et al., 2020). The waisted blades, linguistic and genetic evidence have, until now, provided the only indication for human settlement of this antiquity in the region.

Here we present evidence for human behavioural adaptations to a small island ecosystem which underwent a $\sim 90 \%$ reduction in size $\left(280-30 \mathrm{~km}^{2}\right)$ following the LGM. Systematic excavations were undertaken at the newly discovered archaeological site of Kelebwanagum cave [Pronounced: Kell-ee-bwwa-nah-gum] on the uplifted Miocene-aged limestone island of Panaeati (Louisiade

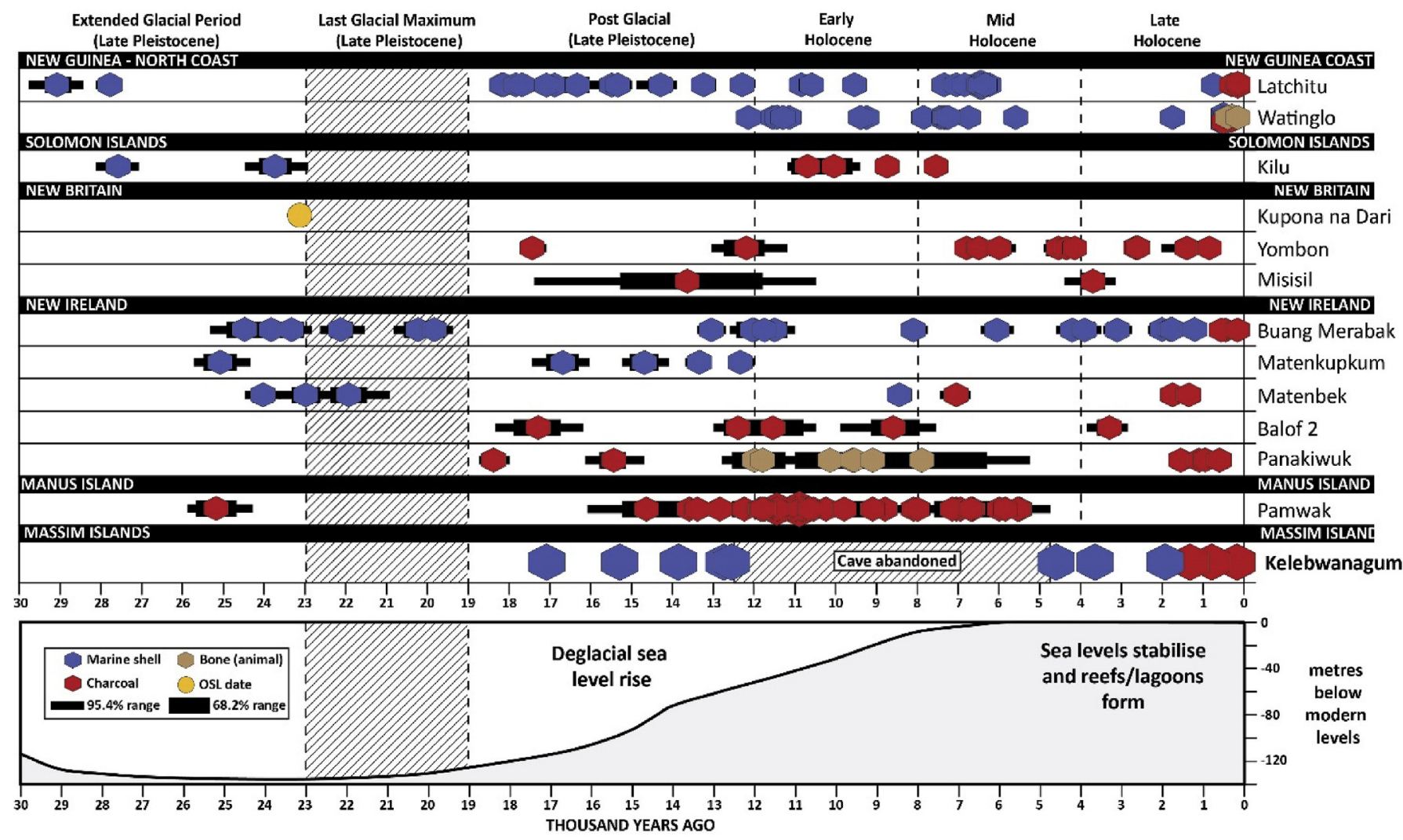

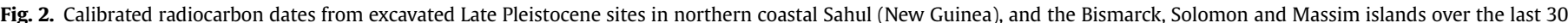

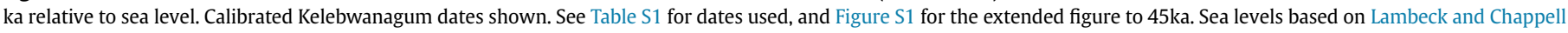
(2001). 
Archipelago, Milne Bay Province; Fig. 1c) (Smith and Pieters, 1973). A cultural sequence from 17.3 to 16.8 cal ka defines Panaeati as the smallest island in Australasia known to have been occupied during the Late Pleistocene and extends records for human occupation in the Massim region by over $14 \mathrm{ka}$. Post-glacial human adaptations to a small island ecosystem in Near Oceania can therefore be modelled, for the first time, against cultural records of a similar age on considerably larger and more stable island environments, as well as from across Sahul. We report the first Late Pleistocene paleoenvironmental record for a Near Oceanic island and define the regional antiquity for inter-island obsidian transfer, shell technology and the arrival of pottery-using cultural groups. The evidence from Kelebwanagum fills a critical gap in understanding the effects of post-glacial sea-level rise on population dispersals in island Near Oceania, which also affected global dispersals (See ArchaeGLOBEProject, 2019).

\section{Site location and setting}

Panaeati Island $\left(30 \mathrm{~km}^{2}, 206 \mathrm{~m}\right.$ asl $)$ is located $170 \mathrm{~km}$ east of the New Guinea mainland and comprises a central meta-volcanic hill surrounded by an uplifted coral limestone platform (Smith and Pieters, 1973). Kelebwanagum cave (S10 $40^{\prime} 28.2^{\prime \prime}$ E152 $21^{\prime} 01.9^{\prime \prime}$, WSW aspect) is situated $160 \mathrm{~m}$ inland at the base of a low-lying limestone rise on the northwest coast where coastal cliffs rise vertically $\sim 10 \mathrm{~m}$ above sea level (Fig. 3). Archaeological investigations were initiated on Panaeati as it is one of the few islands in the Massim region where uplift had likely preserved Late Pleistocene coastal habitation sites against post-glacial sea-level rise. The island is also positioned along one of two major routes into the archipelago at this time (See Fig. 1b).

The densely forested limestone plateau along the northern half of Panaeati was the focus of surveys (Cobb et al., 2004; Paijmans, 1976). The north plateau was the only part of the island where long-term sediment accumulation had occurred and where more extensive uplift had formed overhangs and caves potentially suitable as shelters (Fig. 3a). The limestone on Panaeati likely formed in the Early Miocene (23-16 Ma) (Smith and Pieters, 1969). Coral from lower-lying limestone platforms ( $5 \mathrm{~m}$ asl) on nearby Misima Island $\left(212 \mathrm{~km}^{2}\right.$ ) has been dated to 27.5-26.6 cal ka (See Kaplin, 1994: MGU-593: 23,200 $\pm 180 \mathrm{BP}$ ), providing a possible proxy and minimum age for equivalent uplift on the southern side of Panaeati. There is, however, no established uplift history for the higher northern Panaeati platform where Kelebwanagum cave is located.

A barrier reef and shallow lagoon encloses the southern side of Panaeati and encompasses two smaller islands that prior to and during the LGM formed a single $280 \mathrm{~km}^{2}$ landmass situated only $\sim 40 \mathrm{~km}$ from the coast of Sahul (Fig. S2) (Smith and Pieters, 1973). The vertebrate fauna (bats, birds, snakes, rats and cuscus) on Panaeati are relatively depauperate compared to New Guinea due to its complete isolation (Flannery, 1995; Wikramanayake et al., 2002). Panaeati also receives half the annual rainfall of Misima island (3000-4000 mm), only $14 \mathrm{~km}$ to the east. The central mountain range of Misima is $800 \mathrm{~m}$ higher and frequently traps clouds, generating orographic rainfall. It is one of only a few islands in the region with permanent flowing rivers which can support populations during periods of prolonged drought (Jones and Ellis, 1995).

\section{Results and interpretation}

\subsection{Cave excavation, stratigraphy, and chronology}

In July 2018 , a $100 \times 50 \mathrm{~cm}\left(0.5 \mathrm{~m}^{2}\right)$ trench was systematically excavated near the mouth of Kelebwanagum cave, immediately adjacent to a $60 \times 60 \mathrm{~cm}\left(0.36 \mathrm{~m}^{2}\right)$ spade test pit dug the previous year (Table S2). The cave floor comprised a $15 \mathrm{~m}^{2}$ exposed sedimentary deposit with accumulated solution limestone $\left(7 \mathrm{~m}^{2}\right)$ at the rear of the cave. Excavation removed $6 \%$ of the exposed sediment, and alkaline soils throughout the deposit ( $\mathrm{pH}$ : 9) provided excellent conditions for the preservation of faunal remains (Fig. S3 \& Table S4). Eleven AMS radiocarbon dates on unidentified wood charcoal and identified marine shell recovered in situ provide a well-constrained chronology. Dates are presented as calibrated 95.4\% ranges rounded to the nearest 50 years and 10 years for Pleistocene and Holocene determinations, respectively (Table S3).

Five layers were identified based on colour and particle size, with three major cultural horizons defined using radiocarbon dating and the distribution of material culture (Fig. 4 \& S4). The lower cultural horizon (Layer $5 a-c$ ) reflects cave use during the Late Pleistocene. Habitation at this time is associated with relatively dense shell refuse, an obsidian core and a perforated Turbo argyrostomus tool or ornament. Two dates from a thin basal deposit (Layer 5b) of calcium carbonate hardened sediment indicate initial use from 17,300-15,100 cal. BP (Beta-479384, Beta-502620), and three dates from Layer $5 \mathrm{a} / \mathrm{c}$ define subsequent use from 14,050-12,400 cal. BP (OZX907, Beta-502621, OZX908). Together the dates reflect intermittent and low-density habitation over a 4900-4150 year period. The absence of culturally sterile sediments at the base of the cave suggests human use in the Late Pleistocene may have been the primary mechanism for the onset of sediment accumulation. The date from Layer 5c (OZX908) was the youngest of the Pleistocene series of determinations. The sampled shell had been collected from relatively unconsolidated sediment associated with substantive roof fall accumulation deposited at the cave entrance before the deposition of Layer $4 \mathrm{~b}$ (Fig. S4). Limestone around the entrance likely collapsed following deposition of Layer $5 \mathrm{~b}$, further opening up the cave chamber and creating a larger sediment trap.

The middle cultural horizon (Layer 4a-b) developed following an 8160-7620 year hiatus in human activity and sediment accumulation, reflecting more intensive cave use during the Mid-Late Holocene, with two dates spanning 4780-3480 cal. BP (OZX905, Beta-502622). A third date of 2030-1840 cal. BP (OZX906) was out of sequence and likely derived from anthropogenic disturbance of overlying layers during more intensive use of the cave (Fig. S5). The majority of obsidian and modified shell objects were deposited in the middle horizon, as well as a single pottery sherd. A low volcanic stone wall and clay-based hearth was also identified, perhaps suggesting more regular and sustained cave use (Fig. S4c). Fluctuation in sediment particle size at the Layer $4-5$ interface indicates a break in sediment deposition concordant with the chronological hiatus, as opposed to erosion for which there is no indication. Roof fall debris, aeolian particulate, and faunal activity may have contributed to sediment mixing on the exposed surface during a hiatus in sediment accumulation (Fig. 4 \& S3). The upper cultural horizon (Layers 1-3) spans 1350-1290 cal. BP to 310-0 cal. BP based on three dates (OZX904 to 902). The deposit here contained several shallow fireplaces as well as reduced quantities of shell and obsidian artefacts.

\subsection{Limestone uplift and open site settlement on Panaeati}

To ascertain the timing of uplift for the higher northern and central portion of the limestone plateau on which Kelebwanagum cave is situated buried branch coral from a former lagoon in the interior of the island (Mumwa) was radiocarbon-dated (Fig. 1c). The coral's age extended beyond the limits of radiocarbon indicating uplift had already occurred by at least 46.2 cal ka (Beta-502624). Substantive uplift therefore occurred before the known settlement 

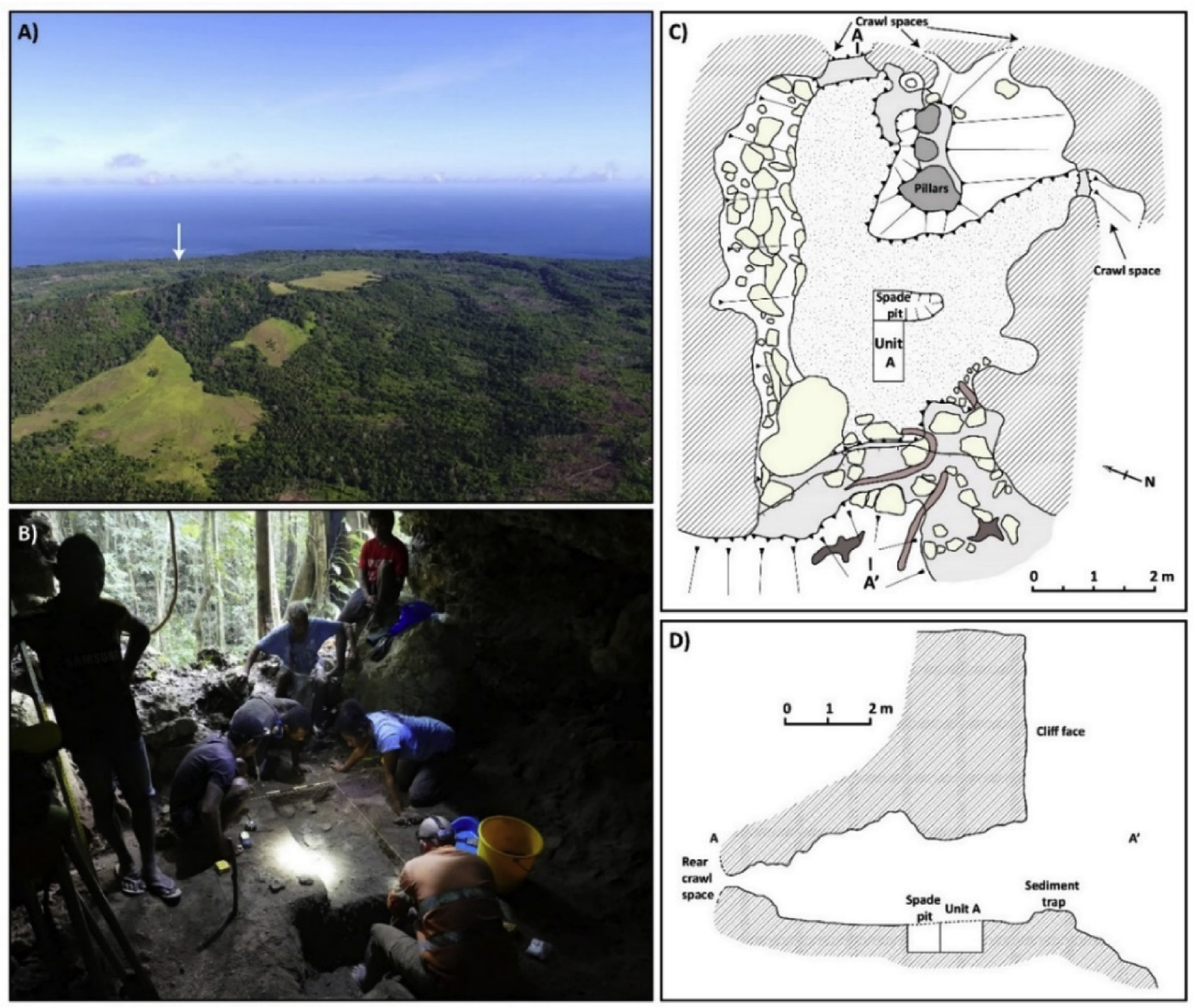

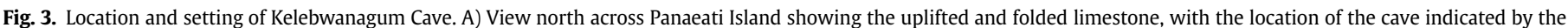
arrow. B) Location of excavation unit within the cave. C-D) Plan and profile of the cave.

of island Near Oceania, demonstrating that changing sea levels will not have affected access to the cave.

Preliminary open site excavations at the Mumwa site further establishes a broader cultural context for the Kelebwanagum cave sequence. Both human visitation and sediment accumulation at Mumwa commenced by 4430-4240 cal. BP (Beta-482842), with habitation becoming increasingly intensive within the past 790 680 cal years (Beta-502623). Numerous limestone niches in the vicinity of Kelebwanagum cave had also been used for secondary human burial from at least 800 years ago, based on relative dating of associated pottery (See Irwin et al., 2019; Shaw, 2019). A human metacarpal on the surface of Kelebwanagum cave indicates it had also been a secondary burial repository in the past.

\subsection{Forest composition since the Late Pleistocene}

The first pollen-based vegetation record for a Near Oceanic island has been developed from sediment samples (3-6, 26-29 and $62-65 \mathrm{~cm}$ ) at Kelebwanagum cave, representing the upper, middle, and lower cultural horizons respectively (See column sample location in Fig. 4a). A total of 607 pollen grains were identified, with higher concentrations in the upper $\left(454,10^{3} \mathrm{x}\right.$ grains $\left./ \mathrm{cm}^{3}\right)$ and lower $\left(50.510^{3} \mathrm{x}\right.$ grains $\left./ \mathrm{cm}^{3}\right)$ horizons relative to the middle horizon $\left(4.910^{3} \mathrm{x}\right.$ grains $\left./ \mathrm{cm}^{3}\right)$. A more detailed analysis of the pollen spectra is forthcoming. The results indicate Kelebwanagum cave had been surrounded by forest canopy since it was first utilised. Cave abandonment from $12,400-4780$ cal. BP was therefore not related to an absence in forest resources (Table S5).

Lower montane forest taxa were present on the island from 17,300 cal. BP (Layer 5a-b, lower cultural horizon) reflecting a response to lower global temperatures at this time. Taxa were composed mostly of Syzygium sp. (Myrtaceae) and to a lesser extent, Euphorbiaceae. Dodonaea shrub species were also prevalent, which indicate an open canopy forest during the Late Pleistocene and may signify early human vegetation clearance around the cave. Forest cover between 4780 and 1840 cal. BP (Layer 4a, middle cultural horizon) was dominated by Myrtaceae and Euphorbiaceae taxa reflecting primary forest composition before sustained anthropogenic disturbance in the area. Within the past 1350 cal. BP (Layer 2-3, upper cultural horizon) forest composition 


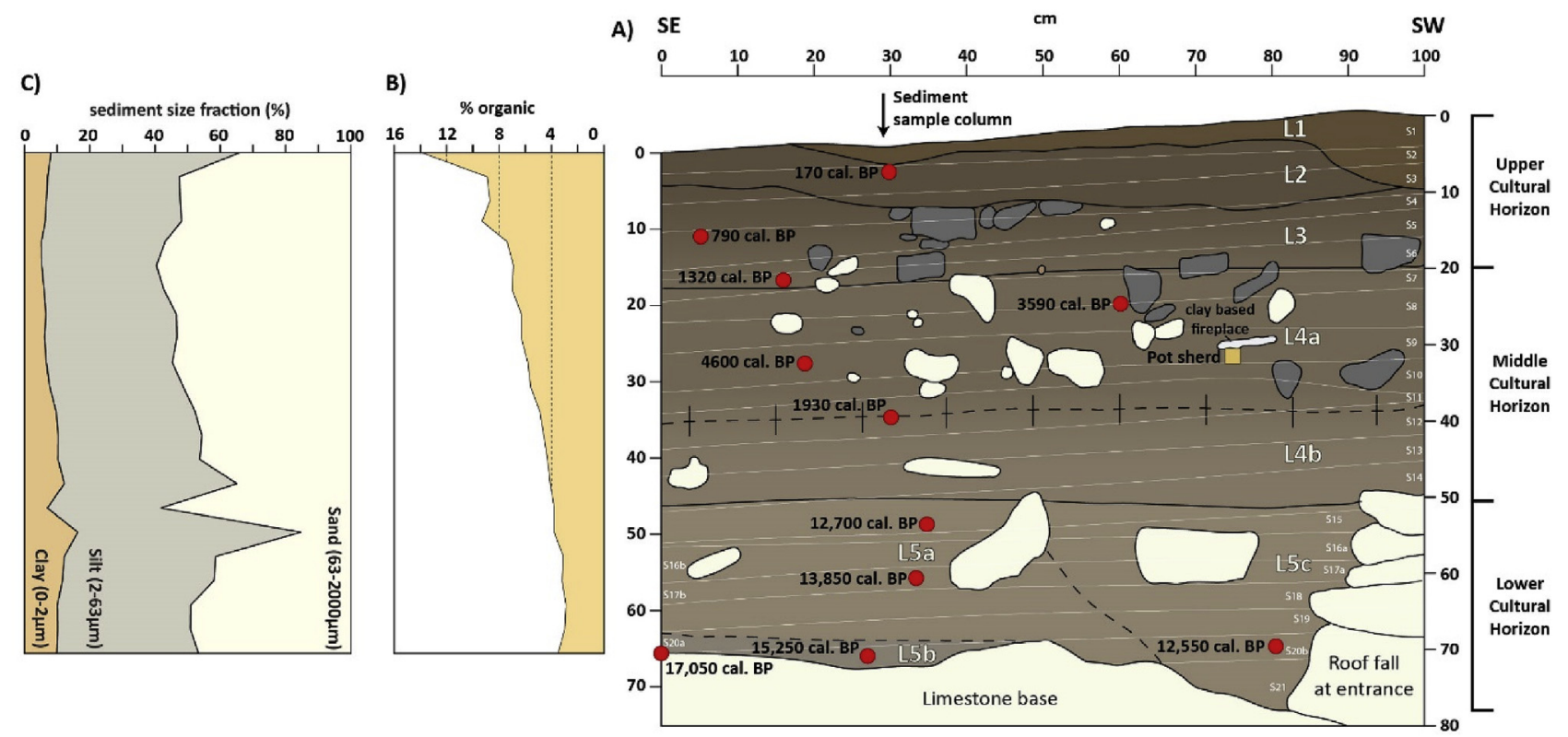

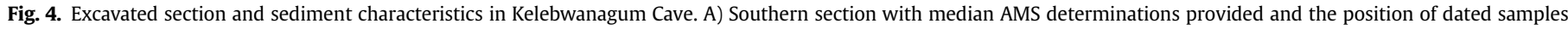

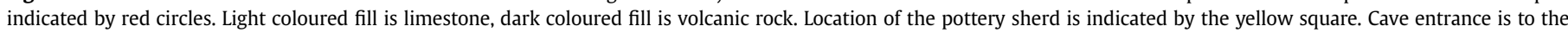

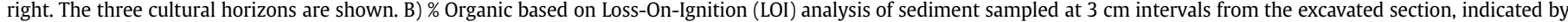

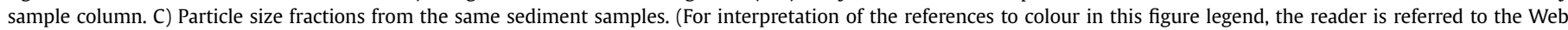
version of this article.)

was similar to the modern-day and comprised lowland forest taxa (Melastomataceae/Combretaceae). Secondary regrowth of disturbance/successional indicator Dodonaea shrub and Trema tree species are consistent with increased landscape use over this time as indicated by the secondary burial niches and occupation of Mumwa.

\subsection{Faunal exploitation reflects changing island ecosystem}

A substantive shellfish assemblage (3350g) demonstrates the exploitation of a more diverse range of genera in the middle and upper horizons ( $<4780-4490 \mathrm{cal}$. BP) compared to the lower horizon (17,300-12,400 cal. BP). Burnt shell (665g) throughout the deposit confirms an association with human use (Table S6; Fig. S6). Chiton (Acanthopleura sp.) and crab (Decapoda) were the most common taxa in the lower cultural horizon (17,300-12,400 cal. BP), which could have been harvested from the limestone shoreline and plateau near the cave. Cave proximity to the sea would not have changed as sea levels fluctuated because of the vertical cliffs, and therefore distance to marine resources would also not have substantively changed. Snails (Nerita sp., Tectarius sp., Camaenidae) were also abundant in the lower horizon, although some land snail may have been deposited naturally. The range of taxa identified from Late Pleistocene contexts at Kelebwanagum was also exploited in similarly aged layers at Buang Merabak and Matenkupkum on New Ireland in the Bismarck Archipelago (See Fig. 2 for site chronologies). Harvesting of these taxa likely reflects low-level opportunistic foraging of shellfish beds on exposed but relatively depauperate limestone shorelines (Gosden and Robertson, 1991; Rosenfeld, 1997).

A marked increase in the density of reef and sandy shore taxa (Turbo sp., Tridacna sp., Trochus sp., Cypraea sp., Conus sp., Cerithiidae and bivalves) in the middle cultural horizon (Layer $4 \mathrm{a}-\mathrm{b}$ ) demonstrates a substantive shift in the availability of exploitable habitats, with beaches and reef systems established around the island by the mid-Holocene. A coincident middle horizon peak in hardshore taxa also suggests cave use had generally increased at this time, with a subsequent reduction in the quantity of harvested shellfish in the upper cultural horizon. A decrease in shellfish exploitation over the last millennium may relate to increased habitation intensity of open sites elsewhere on the island, as has been identified at the interior Mumwa site.

The faunal bone (NISP $=99 ; 10 \mathrm{~g}$ ) assemblage indicates only marine resources (turtle and fish) were exploited in the lower cultural horizon, whereas both marine and terrestrial fauna were harvested in the middle and upper horizons (Table S7). Most marine bone was calcined from fire confirming human predation, and bird bone had fracture patterns consistent with hunting and processing. However, digestion pitting on lizard, frog, snake and tetrapod bone likely occurred from bird predation and is therefore considered in this context as non-anthropogenic. A Phalangeridae (Cuscus) tooth and Murid maxilla from the middle cultural horizon (4780-1840 cal. BP) provides a minimum antiquity for the translocation of these animals to the Massim islands (see Taylor et al., 1982). A Requiem shark bone (Carcharhinidae) in the upper cultural horizon suggests hunting strategies included larger marine taxa within the past $1350-1290$ years.

\subsection{Low-density obsidian transfer since Late Pleistocene}

Eleven obsidian pieces were recovered from excavation, including a bipolar core (2.03 g) from the lower cultural horizon demonstrating a Late Pleistocene antiquity for inter-island obsidian transfer in the Massim (Figs. 5a \& 6a). Late Pleistocene obsidian transfer to Kelebwanagum cave was relatively limited compared to in the Bismarck Archipelago where larger quantities were being transported to cave localities (Matenkupkum, Matenbek and Buang Merabak) from New Britain sources by 24 to 22 cal. ka. Obsidian in the middle $(n=6,1.09 \mathrm{~g})$ and upper $(\mathrm{n}=4,0.77 \mathrm{~g})$ cultural horizons included complete flakes, flake fragments and a bipolar core fragment. A lack of debitage and their small size $(X=11 \mathrm{~mm})$ suggests technology was not formalised, and reduction did not occur inside 
A)

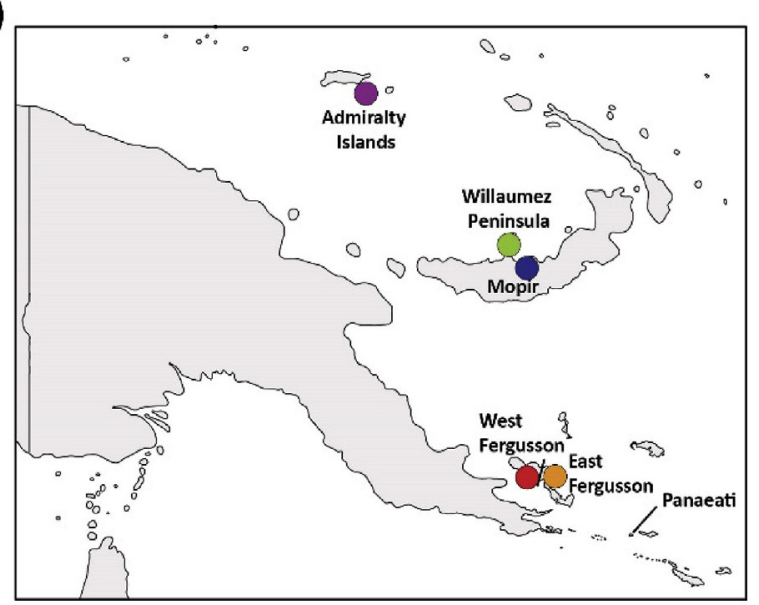

B)

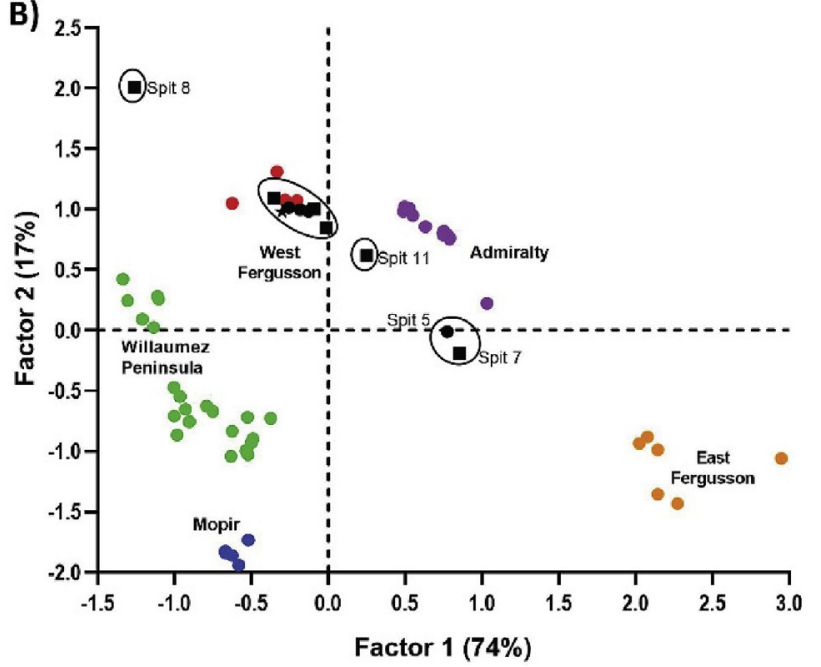

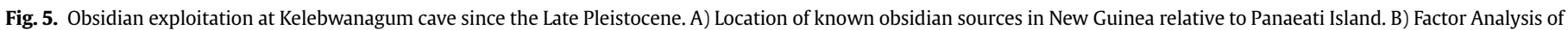

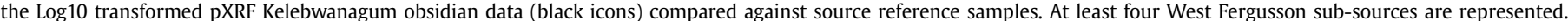
Star $=$ Lower cultural horizon, square $=$ Middle cultural horizon, circle $=$ upper cultural horizon.

the cave (Table S11). No other modified lithic types were recovered from the excavated deposit.

The obsidian was chemically characterised using portable X-Ray Fluorescence spectrometry (pXRF) to determine source origin. All eleven pieces were attributed to the West Fergusson Island source region, located $\sim 200 \mathrm{~km}$ west of Panaeati. Four groupings were identified which reflect chemical variation between obsidian flows across West Fergusson, and do not correlate to the size of the obsidian pieces. All four sub-sources were exploited in the middle cultural horizon, and two in the upper horizon (Figs. 5b \& 6a, Tables S8-11). The wider range of sub-sources utilised in the middle horizon tentatively suggests an expanded interaction network from 4780 to $4490 \mathrm{cal}$. BP associated with increased movement of people into and between islands. Increased inter-island mobility from this time is consistent with models of expanding social interaction networks across highland-lowland New Guinea, the Bismarck Archipelago and the Massim throughout the mid-Holocene based on the distribution and dating of formally manufactured pestles, mortars and stemmed obsidian tools (Shaw et al., 2020b; Swadling, 2016; Torrence and Swadling, 2008).

\subsection{Late Pleistocene antiquity and Holocene proliferation of shell technology}

A perforated Turbo argyrostomus shell net sinker or ornament from the lower cultural horizon also extends the known antiquity of shell technology in the Massim islands to the Late Pleistocene (Fig. 6p). Use wear around the circumference of a well-defined perforation on the outer whorl of the shell suggests it was hung from a fibrous string, with flaking around the aperture margin indicating deliberate manufacture distinct from food processing breakage (Table S12). The T. argyrostomus object is functionally similar to Turbo sp. shell technology identified at the New Ireland sites of Matenbek and Matenkupkum dating from at least 24-22 cal. $\mathrm{ka}$. Shell reduction at these sites has been argued to reflect fishing technology, and perhaps the production of hooks (Gosden and Robertson, 1991; Smith and Allen, 1999).

The evidence from Kelebwanagum cave and the Bismarck Archipelago together suggests Turbo sp. shells were deliberately selected for tool manufacture because of their shape and robust matrix (Smith and Allen, 1999).
A proliferation of shell technology in the Mid-Late Holocene was evident and is correlated with the emergence of a more diverse range of shellfish habitats, including lagoonal reefs and beaches. Functional and ornamental shell artefacts from the middle $(\mathrm{n}=8)$ and upper $(\mathrm{n}=3$ ) cultural horizons included scrapers, beads and utilised flakes manufactured from at least six shellfish taxa (Cypraea sp., Turbo sp., Conus sp., Tectarius sp., Asaphis sp. and Tridacna sp.) (Fig. 6e,i-o). A possible bead made from a bird bone diaphysis was also identified in the middle horizon (Fig. 6f).

\subsection{Pottery introduction, origins, and Late Holocene cultural influences}

A single slipped plain body pottery sherd from the middle cultural horizon (4780-1840 cal. BP: Fig. 6c) was technologically consistent with the earliest pottery traditions in the Pacific region associated with the Lapita Cultural Complex, dating from 3250 to 3150 cal. BP (Specht and Gosden, 2019; Summerhayes et al., 2010b). Distinctively decorated Lapita pottery (dentate stamped) is recognisable in the Bismarck Archipelago and elsewhere in New Guinea through to $2500-2350 \mathrm{cal}$. BP, after which time regional traditions and interaction patterns emerge (David et al., 2012; Summerhayes, 2007). The sherd was recovered from beneath an intact clay-based hearth and is considered to be from a secure context.

Scanning electron microscopy with energy dispersive spectroscopy determined the composition of the sherd as containing shell, coral, quartz, and ilmenite. The inclusions are consistent with a volcanic beach sand temper (Fig. S7). Calcareous tempered pottery with volcanic sands has previously been recovered from a Lapita site on Wari Island in the Massim dating from 2800 to 2600 cal. BP (See Fig. 1b for site locations). By contrast, calcareous Lapita pottery on Nimowa Island dating from 2500 to $2300 \mathrm{cal}$. BP did not contain volcanic minerals as islands in the southeast Massim are not of volcanic origin (Chynoweth et al., 2020; Negishi and Ono, 2009; Shaw et al., 2020a). An age range of 3250-3150 to 2800$2600 \mathrm{cal}$. BP is therefore attributed to the Kelebwanagum sherd, falling within the established middle horizon cave chronology.

Ilmenite is not present in the bedrock of islands in the Louisiade Archipelago. However, it is present in metamorphic core complexes on Fergusson Island within the same vicinity as the exploited obsidian outcrops. Therefore, Fergusson Island is the likely origin 


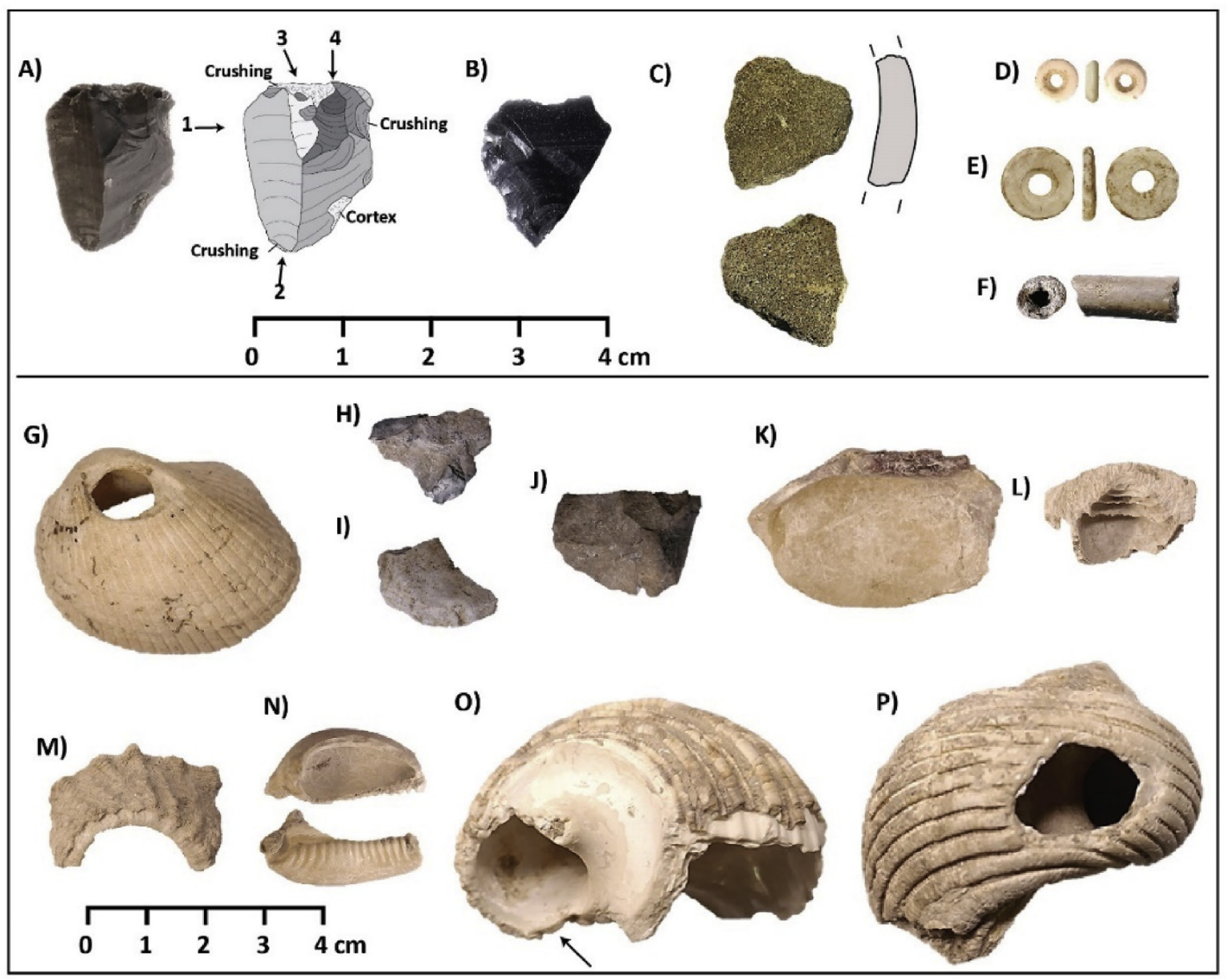

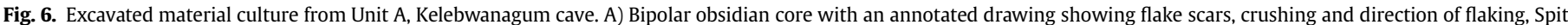

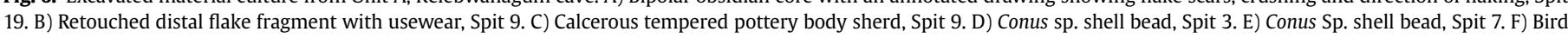

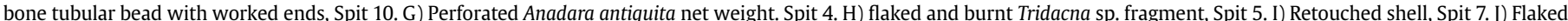

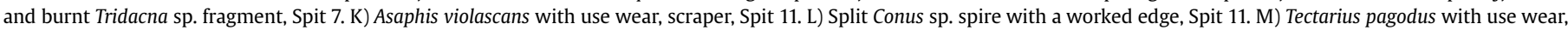

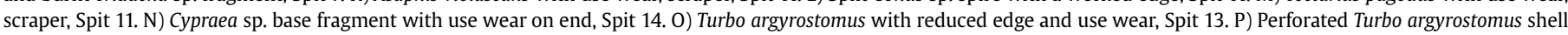
with use wear, possibly a net weight, Spit 16 .

for the potsherd (Davies and Ives, 1965; de Keyser, 1961; Monteleone et al., 2007; Shaw, 2016a; Smith and Pieters, 1969). While only a single sherd, it provides a strong indicator of the timeframe and direction for the arrival of Lapita cultural groups into the Massim which profoundly influenced genetic and cultural diversity (Shaw, 2019; van Oven et al., 2014). A high degree of language replacement also occurred in the millennia following Lapita arrival (Ross, 1988).

\section{Discussion}

Climatic changes leading up to and during the LGM have long been considered global drivers for the dispersal of modern human populations (Will et al., 2019). It is now becoming clear that the subsequent millennia were also critical in shaping human diversity in coastal and island post-glacial landscapes as sea levels inundated vast shallow stretches of the continental shelf ( $\mathrm{O}^{\prime} \mathrm{Connell}$ and Allen, 2007; O'Connor et al., 2019). Although people migrated across Sahul and into the interior relatively quickly following colonisation, coastlines remained attractive areas of habitation with marine resources forming an important component of subsistence regimes (Hiscock, 2008; Smith, 2013; Veth et al., 2017). However, most coastal Late Pleistocene landscapes are now underwater, and few islands existed around Sahul prior to the Holocene. The unique position of islands in the Massim region - on a shallow continental shelf and close to the New Guinea coast - has allowed investigations to provide novel insights on modern human adaptive behaviours to small island ecosystems and in response to post-LGM deglacial sealevel rise.

\subsection{Cave use and abandonment as adaptive behaviour}

Kelebwanagum cave provides the only Late Pleistocene record of human occupation in the Massim Island Region. Initial cave use by 17,300-16,800 cal ka occurred when sea levels had risen $20-25 \mathrm{~m}$ from their lowest levels during the early stages of global deglaciation. Both the timing and location of the cave suggests people had begun utilising the higher limestone platform on Panaeati $(\sim 10 \mathrm{~m}$ asl) as lower-lying coastlines became increasingly unstable. The timing of initial use may also reflect expansion or perhaps reexpansion of people into the Massim islands which were less attractive for settlement during the LGM, as has been modelled archaeologically in the Bismarck Archipelago and Wallacea (Leavesley, 2006; O'Connor et al., 2019). Genetic evidence supports this model with the diversification of mitochondrial genomes in the Massim and the Bismarck Archipelago during and after the LGM, 
from 26-18 ka (Pedro et al., 2020).

There is currently a lack of evidence for pre-LGM island habitation in the Massim. However, the presence of lower montane economic tree taxa in the lower cultural horizon of Kelebwanagum cave does indicate forest resources had adapted to colder climatic conditions during the LGM. Forest resources could therefore have supported a substantive vegetation base for pre-agricultural populations to exploit. If people were present in the Massim before 17.3-16.8 ka, populations would likely have been centred near lower-lying and gently sloping coastlines where marine craft landings, sheltered moorings and fringing reef food resources could be more readily accessed.

An apparent lack of cave use at Kelebwanagum during the extended glacial period (30-18 ka, see Reeves et al., 2013), when sea levels were lowest and islands largest, indicates extreme sealevel drawdown did not influence population movements to the higher coastline of northern Panaeati. However, as sea levels rose, it would have been necessary to follow the coast inland or to move away from low-lying areas. The vertical limestone cliffs near Kelebwanagum cave would have provided a stable shoreline resistant to rising seas and tsunamis. Breaks in the cliff structure would have also allowed ongoing access to hardshore shellfish beds. The low density of material culture suggests only small groups of people had intermittently utilised the cave during the Late Pleistocene and were likely relatively mobile across these island landscapes. Such a pattern is consistent with Pleistocene records from the Bismarck Archipelago (Allen and Gosden, 1996; Gosden and Robertson, 1991; Leavesley, 2006; Summerhayes et al., 2017).

Apparent abandonment of Kelebwanagum cave after $12,650-12,400$ cal. BP coincided with substantive flooding of the continental shelf around Sahul and globally. Over the time the cave was used during the Late Pleistocene sea levels had risen a further $60 \mathrm{~m}$ at a relatively rapid rate of $1 \mathrm{~m}$ per 82 years. Such a rise would have drowned established coral reefs and gradually but significantly increased the distance between Panaeati and Sahul by as much as $130 \mathrm{~km}$ (Fig. 2) (Chappell and Polach, 1991; Webster et al., 2018). Over this time and in the millennia after $12,400 \mathrm{cal}$. BP the island reduced in area by $90 \%$, with up to $250 \mathrm{~km}^{2}$ of the vegetated landscape and freshwater catchments no longer available as a subsistence base to support pre-agricultural populations. Such a marked reduction was likely a tipping point that innovations in technology or social organisation were not able to overcome. It is likely populations at this time re-located to Sahul or to larger and steeper islands where sea-level rise had a less pronounced effect on land area reduction.

Reuse of Kelebwanagum cave in the middle cultural horizon from 4780-4490 cal. BP occurred under vastly different ecological conditions. The shellfish assemblage indicates a lagoonal-reef system had formed around parts of Panaeati and sea levels had stabilised 1-3 m above current levels (Dickinson, 2003) (See Fig. 1c). Western Pacific coral records indicate reef growth commenced or increased substantively on many islands during the mid-Holocene (8.2-4.2 ka), with beach ridges also beginning to form in emerging lagoon environments (Dickinson, 2014; Woodroffe et al., 2000). Sheltered waters within lagoons and the increased number of sand bars/atolls between Panaeati and New Guinea from the end of the mid-Holocene would have enabled more regular interaction between islands. Settlement and sediment accumulation at the Mumwa open site in the interior of Panaeati commenced from 4430 to $4240 \mathrm{cal}$. BP, which is equivalent in age to the middle cultural horizon. The coincident timing suggests the island was probably abandoned during the prolonged hiatus in cave use, with people returning to the island by the end of the Mid-Holocene.

\subsection{Landscape use across Sahul and island Near Oceania during post-LGM deglaciation}

The Kelebwanagum cave sequence, when integrated with Late Pleistocene records from elsewhere in Island Near Oceania and Wallacea, indicates increased levels of population movement in these regions coincided with the lower cultural horizon at Kelebwanagum cave (17,300-12,400 cal. BP). In the Bismarck Archipelago, only two cave sites (Buang Merabak and Matenbek) have evidence for LGM habitation (Fig. 2), during which time other sites were either abandoned or ephemerally utilised (Allen et al., 1988; Leavesley, 2004). These two Bismarck cave sequences may reflect deliberate retraction of populations to densely forested refugia ecosystems in southern New Ireland during the LGM. Whatever the case, initial habitation of two rockshelters (Panakiwuk, Balof 2) and reuse of other previously inhabited locales (Matenkupkum, Yombon, Latchitu, Pamwak) within a relatively defined period of 18.4 to $14.7 \mathrm{cal} \mathrm{ka}$ indicates an expansion of populations back into a broader range of island ecosystems soon after the LGM (Allen and Gosden, 1996; Allen et al., 1988; Gosden and Robertson, 1991; O'Connor et al., 2011; Pavlides, 2004) (Fig. 2). A similar pattern of landscape use is also evident on Kisar, Timor and Alor Islands in Wallacea (Hawkins et al., 2017; O'Connor et al., 2019; Samper Carro et al., 2016).

Across Sahul as well, settlement patterns changed in the millennia following the LGM as people responded to significant changes in temperature, aridity and sea level (Maloney et al., 2018; O'Connor and Veth, 2006; Slack et al., 2009; Smith, 2013; Veth, 1993). From 20 to $19 \mathrm{Ky}$ deglaciation had commenced and sea levels had begun to rise which eventually flooded up to one-third of Australia's continental landmass. A meta-analysis combining 477 radiocarbon dates from 136 sites across south-central Sahul (Australia) spanning the period 25-12 ka demonstrates that population density increased within well-resourced 'refugia' regions between 19 and $15 \mathrm{ka}$ (Williams et al., 2013). Patterns of population expansions therefore spanned island, coastal and interior landscapes of Sahul and Near Oceania, reflecting adaptive settlement strategies in response to changes in ecosystem habitability.

\subsection{Island refugia and cultural diversity}

Large islands $\left(>100 \mathrm{~km}^{2}\right.$ ) with steep bathymetry in the Massim region were likely to have been refugia as low-lying islands flooded and significantly reduced in area. Rossel Island, although having reduced in size by as much as $70 \%$ during deglacial sea-level rise, maintained a relatively large land area $\left(290 \mathrm{~km}^{2}\right)$. The presence of waisted stone tools on Rossel suggests habitation and vegetation clearance occurred sometime during the Late Pleistocene (Groube, 1989; Shaw, 2017). Except for Rossel, all Massim island populations speak Austronesian languages which are linked with the expansion of Lapita cultural groups into the region some 3000-2500 years ago (McNiven et al., 2011; Negishi and Ono, 2009; Ross, 1988). Although Panaeati was inhabited during the Late Pleistocene the language/s once spoken on the island must have been entirely replaced following the arrival of Lapita cultural groups in the Late Holocene. By contrast, the unique language and genetic patterning of Rossel Islanders strongly suggests greater structural preservation of this population since the Late Pleistocene. Yet, until now, archaeological evidence to support settlement of this antiquity in the Massim had been lacking, which precluded the region's inclusion in global models of Late Pleistocene modern human dispersals (Dunn et al., 2008; Levinson, 2008; Liep, 2009; van Oven et al., 2014). 


\section{Conclusion}

Kelebwanagum cave has provided evidence for human settlement on the smallest island in Australasia during the Late Pleistocene, and the first evidence for settlement of this antiquity in the Massim region. The available evidence indicates that the uplifted limestone island of Panaeati was an ecological refugia from 17.3 to $16.8 \mathrm{cal}$ ka as lower-lying islands and coastlines became unstable as a result of post-LGM deglacial sea-level rise. Kelebwanagum cave, and perhaps also the island, was abandoned by $12.4 \mathrm{cal}$. ka. When the timing for Late Pleistocene cave use and abandonment is modelled against cultural records dating to before, during and after the LGM across island Near Oceania and Sahul, an inter-regional pattern for population re-location and adaptation is apparent. We argue these adaptations in landscape use and social behaviour occurred in response to post-glacial climatic conditions affecting habitability and had a profound effect on emerging cultural diversity.

\subsection{Materials and methods}

\subsubsection{Excavation procedure}

Systematic excavation was undertaken by trowel within apparent stratigraphic layers. Excavation proceeded in $3-4 \mathrm{~cm}$ spits except where it was necessary to increase spit depth due to notable changes in sediment characteristics. All sediment was wet and dry sieved through $3 \mathrm{~mm}$ mesh. Excavation proceeded until bedrock was reached. A datum was established before digging commenced, and all measurements were taken using a dumpy level, stadia rod and hand tape. In situ finds, including charcoal fragments, were bagged individually with context numbers and their location recorded in three dimensions. Hearths were excavated and labelled individually as features. Feature depth was determined by measuring the horizontal and vertical position in the square where it was first identified and at its deepest point. The sieve residues were bagged, weighed and sorted. Sediment samples were collected during excavation, and the unit backfilled when excavation was completed. The site elevation profile was surveyed with a dumpy level.

\subsubsection{Radiocarbon dating}

Radiocarbon determinations were obtaining using Accelerator Mass Spectrometry (AMS) at BETA Analytic (Miami, Florida, US) and the Centre for Accelerator Science at ANSTO (Sydney, NSW, Australia). All charcoal and marine shell samples were physically cleaned of sediment adhering to the surface. The samples were pretreated using the acid-base-acid method, by washing the samples with hot $\mathrm{HCl}$ acid to eliminate carbonates, then washed with $\mathrm{NaOH}$ to remove secondary organic acids, followed by a final $\mathrm{HCl}$ rinse to neutralise the solution before drying. Pretreated samples were combusted to $\mathrm{CO}_{2}$ gas by oxidation then reduced to graphite for AMS analysis (Fink et al., 2004; Hua et al., 2001). All ${ }^{14} \mathrm{C}$ determinations were calibrated using the IntCal13 or Marine13 calibration curves (Reimer et al., 2013) and the OxCal 4.3 program (Ramsey, 2009). No island-specific $\Delta \mathrm{R}$ value is available for Panaeati Island, although regional datasets for the Massim suggest minimal old carbon effects in Late Holocene marine shell samples (Petchey and Ulm, 2012). Nonetheless, the western Massim value of $38 \pm 14$ was used to counter potential hard water effects of dissolved limestone uptake in locally harvested shellfish since the Late Pleistocene (Petchey et al., 2008).

\subsection{3. $p H$ and munsell soil analyses}

$\mathrm{pH}$ was determined on a sediment sample fraction using a Searles soil pH test kit. Several drops of indicator liquid were added to the sediment to make a paste, and the indicator powder added. The colour of the powder was recorded after waiting $30 \mathrm{~s}$. Sediment colour was determined by matching dry samples with a Munsell (2000) soil chart.

\subsubsection{Particle size analysis}

Approximately 1-3 g of sediment was sieved through $2000 \mu \mathrm{m}$ mesh, and pretreated with $30 \% \mathrm{NaOH}$ heated to $80-90{ }^{\circ} \mathrm{C}$ to dissolve the organic component. Reverse osmosis (RO) water and several drops of $5.5 \mathrm{~g} / \mathrm{L}$ sodium hexametaphosphate $\left[\left(\mathrm{NaPO}_{3}\right)_{6}\right]$ were added to the sample as a particle deflocculant $24 \mathrm{hrs}$ before analysis (Beierle et al., 2002; Sperazza et al., 2004). A Malvern mastersizer 2000 laser-diffraction particle size analyser with a Hydro2000G dispersal unit was used. Three consecutive runs (15s; 15,000 measurements) were made for each sample, with the average reported. Obscuration was kept within the accepted range of $10-20 \%$. Particle size parameters were calculated using GRADISTAT software using the following grain size dimensions: Clay $<2 \mu \mathrm{m}$, silt: 2-63 $\mu \mathrm{m}$, sand: 63-2000 $\mu \mathrm{m}$ (Blott and Pye, 2001).

\subsubsection{Loss on ignition analysis}

Sediment samples of approximately $1 \mathrm{~cm}^{3}$ were placed in a labelled and weighed crucible and weighed again. The samples were oven-dried at $105{ }^{\circ} \mathrm{C}$ for $24 \mathrm{~h}$ and reweighed to give the dry mass. The samples were then fired in a muffle furnace at $550{ }^{\circ} \mathrm{C}$ for $4 \mathrm{~h}$, with the remaining ash weight representing the minerogenic fraction (Chambers et al., 2011). The percentage of mass lost between oven-dry weight and ash weight represents the organic component (\%) of the sediment. All samples were placed in a desiccating jar to cool before being weighed on a $0.001 \mathrm{~g}$ balance.

\subsubsection{Obsidian artefact analysis}

All lithic material was assessed to identify raw material and reduction characteristics. The following technological categories were used: tool, core, complete flake, flake fragment (medial, distal, longitudinal), and angular fragment. Retouch and usewear were also recorded, defined by deliberate flaking on the margins to create a useable edge, and smaller chipping along a side of the stone respectively. A tool was any artefact that has been modified through shaping for use, and often includes use wear and retouch. A flake is a stone artefact with a defined ventral and dorsal surface, as well as at least one of the following: a platform, bulb of percussion, ripple marks, distal termination. A flake fragment has some of the identified flake characteristics. A core is a parent piece of raw lithic material with negative flake scarring. An angular fragment is any piece of stone produced during the flaking process but does not contain the attributes of a flake (Holdaway and Stern, 2004).

\subsection{7. $p X R F$ analysis of obsidian}

The Kelebwanagum obsidian $(\mathrm{N}=11)$ and 53 obsidian geological samples from all known sources in Papua New Guinea were analysed using an Olympus Delta Premium Portable XRF Spectrometer at the University of New South Wales Mark Wainwright Analytical Centre. Obsidian samples were analysed three times each using the in-built Geo-chem mode with elemental composition recorded in parts per million ( $\mathrm{ppm}$ ). Final values were an average of the three runs. Two X-Ray beams, operating at $40 \mathrm{keV}$ and $10 \mathrm{keV}$, were emitted from a Rhodium tube anode. Each beam was run for $90 \mathrm{~s}$, with a total analysis time of $180 \mathrm{~s}$ per sample. The spectrometer was calibrated against the factory standard Alloy 316 Stainless Steel at the beginning of each testing period to ensure the $\mathrm{X}$-Ray beams and detectors were functioning correctly (Sheppard et al., 2010; Torrence et al., 2013).

Obsidian specific spectrometer calibration was developed using 29 pelletised geological standards with elemental concentrations 
and ranges spanning the known range of obsidian sources (JA-3, VS-N, DT-N104, W-2, SDC-1 2010, RGM-1, MRG-1, DNC-1, BIR-1, SCO-1, MA-N, BE-N, AN-G, SY-3, SY-2, JB-10a, JB-1, MAG-1, JR-2, GXR-6, GXR5 (2), GXR-2, JLK-1, JG-1, JB-2, JB-3, JG-2, NBS69b (2), NIM-G). Element specific calibration factors were determined using linear regression offsets between pXRF data and published values (Potts et al., 1992). Two obsidian geological standards (NIST278 and RGM-2) were analysed at the beginning and end of each run and between every four samples. Principal component analysis (PCA) was undertaken using SPSS Statistics Package Version 23.0 with Mn, $\mathrm{Fe}, \mathrm{Zn}, \mathrm{Rb}, \mathrm{Sr}, \mathrm{Y}, \mathrm{Zr}$, Nb elemental concentrations. Values were transformed using a base-10 logarithm before statistical analysis (Glascock and Neff, 2003).

\subsection{Faunal analysis}

Faunal remains were identified by comparison with the ANU Archaeology and Natural History Osteology Laboratory reference collection. Skeletal elements were identified to the lowest taxonomic level possible. The assemblage was quantified using Number of Identified Specimens (NISP) as NISP typically tracks Minimum Number of Individuals (MNI) closely to relative abundance and avoids issues of aggregation, interdependence, and sample size (Lyman, 2008). The taphonomy of the vertebrate assemblage was assessed by observing bone surface modifications under light magnification (x10). Bone modifications examined included signs of butchery via cut marks and fracture patterns, as well as burning.

\subsection{Shellfish analysis}

Shellfish remains were analysed at UNSW. Gastropod and bivalve shells were separated into taxa, quantified by weight ( $\mathrm{g}$ ), with the aid of Hinton (1975) and Cernohorsky (1972). Further analysis is underway to quantify MNI for each shell taxon. Four major environmental zones were used to characterise the known preferred shellfish habitats - sand inter-tidal, rock inter-tidal, reef inter-tidal and mangrove, following Wells and Kinch (2003), and Bedford (2006).

\subsection{Scanning electron microscopy (SEM) and energy dispersive spectroscopy (EDS)}

The potsherd was resin mounted and its surface ground and polished using a sequence of $\mathrm{SiC}$ and diamond polishing pads to a $1 \mu \mathrm{m}$ finish. The polished sample was evaporatively coated with $\sim 25 \mathrm{~nm}$ carbon to provide a conductive surface. SEM imaging was conducted using a Hitachi S-3400N SEM; EDS analysis was done using a Bruker XFlash SDD-EDS detector fitted to the SEM. A beam energy of $20 \mathrm{kV}$ was used for both imaging and analysis.

\subsection{Sediment pollen analysis}

Bulk sediment samples of $2 \mathrm{~cm}^{3}$ volume were homogenised and prepared using standard $\mathrm{HCl}, \mathrm{KOH}$ and acetolysis pollen processing methods described in Fagri and Iversen (1989). Lycopodium marker grains were added to permit calculation of pollen concentrations (Stockmarr, 1971). Lithium polytungstate was used at a specific gravity of 2.0 to further concentrate pollen in the samples (Caffrey and Horn, 2013). Pollen grains were identified to the lowest taxonomic level possible using a Zeiss Axiophot microscope at 400x and 1000x magnification. Terrestrial pollen counts exceeded 100 grains per sample and identifications were based on the Australasian Pollen and Spore Atlas (apsa.anu.edu.au; APSA-Members, 2007), the pollen reference collection at the Australian National University.

\section{Declaration of competing interest}

The authors declare that they have no known competing financial interests or personal relationships that could have appeared to influence the work reported in this paper.

\section{Acknowledgements}

The authors would like to thank the community on Panaeati Island for permission to undertake the research, in particular, to Lincoln Wesley and his family for hosting us and having a central role in the community engagement. Thank you to Lousane and Joe Norman, the East and West Panaeati councillors for their support. We also thank the National Museum and Art Gallery of Papua New Guinea, namely Alois Kuaso, the National Research Institute, namely Georgia Kaipu, and the Provincial Government of Milne Bay for supporting the research program. The authors would like to acknowledge Sarah Kelloway and Irene Wainwright of the XRF Facility within the Mark Wainwright Analytical Centre at the University of New South Wales for pXRF support. SEM-EDS was conducted at the UNSW Sydney node of the Microscopy Australia network. Thank you to Glenn Summerhayes and Matthew Spriggs for reading a draft manuscript.

\section{Appendix A. Supplementary data}

Supplementary data to this article can be found online at https://doi.org/10.1016/j.quascirev.2020.106522.

\section{Funding}

The project was funded by an Australian Research Council Discovery Early Career Award (DECRA, DE170100291) awarded to Shaw for the period 2017-2019, and by the University of New South Wales Faculty of Science. Radiocarbon dating was partly funded by an Australian Nuclear Science and Technology Organisation grant AP11908. We acknowledge the financial support from the Australian Government for the Centre for Accelerator Science at ANSTO through the National Collaborative Research Infrastructure Strategy (NCRIS).

\section{Data and materials availability}

All data are available in the main text and in the supplementary materials.

\section{Author contribution}

B.S. formulated and obtained funding for the project. B.S., S.C. and J.H. developed the excavation strategy and conducted the excavations. E.H. conducted the pXRF analysis of the obsidian. E.H., S.C. and B.S. analysed the obsidian artefacts. B.S. conducted the particle size and loss on ignition analyses of the sediments, the pottery, lithic, and shell artefact analyses, and the shellfish subsistence analysis. S.H. and F.H. undertook the sediment pollen analysis. K.P. and B.S. completed the SEM/EDS analysis of the pottery. S.H. analysed the faunal bone assemblage. G.J. facilitated the radiocarbon dating. B.S. drafted the manuscript, with all co-authors contributing to the final version.

\section{References}

Allen, J., Gosden, C., 1996. Spheres of interaction and integration: modelling the culture history of the Bismarck Archipelago. In: Davidson, J.M., Irwin, G.J., Leach, B.F., Pawley, A., Brown, D. (Eds.), Oceanic Culture History: Essays in 
Honour of Roger Green. New Zealand Journal of Archaeology Special Publication, Auckland, pp. 183-197.

Allen, J., Gosden, C., Jones, R., White, J.P., 1988. Pleistocene dates for the human occupation of New Ireland, northern Melanesia. Nature 331, 707-709. https:// doi.org/10.1038/331707a0.

Allen, J., O'Connell, J.F., 2014. Both half right: updating the evidence for dating first human arrivals in Sahul. Aust. Archaeol. 79, 86-108. https://doi.org/10.1080/ 03122417.2014.11682025.

APSA-Members, 2007. The Australasian Pollen and Spore Atlas v1.0. Australian National University, Canberra.

ArchaeGLOBE-Project, 2019. Archaeological assessment reveals Earth's early transformation through land use. Science 365, 897-902. https://doi.org/ 10.1126/science.aax1192.

Beaton, J.M., 1995. The Transition on the coastal fringe of Greater Australia. Antiquity 69, 798-806. https://doi.org/10.1017/S0003598X0008234X.

Bedford, S., 2006. Pieces of the Vanuatu Puzzle: Archaeology of the North, South and Centre. Pandanus Books, Canberra.

Bedford, S., Spriggs, M., Burley, D., Sand, C., Sheppard, P., Summerhayes, G., 2019. Debating Lapita: distribution, chronology, society and subsistence. In Bedford, S., Spriggs, M. (Eds.), Debating Lapita: Distribution, Chronology, Society and Subsistence. ANU Press, Canberra, pp. 5-33.

Beierle, B.D., Lamoureux, S.F., Cockburn, J.M.H., Spooner, I., 2002. A new method for visualizing sediment particle size distributions. J. Paleolimnol. 27, 279-283. https://doi.org/10.1023/A:1014209120642.

Bird, M.I., Condie, S.A., O'Conner, S., O'Grady, D., Reepmeyer, C., Ulm, S., Zega, M., Saltre, F., Bradshaw, C.J.A., 2019. Early human settlement of Sahul was not an accident. Sci. Rep. 9, 8220. https://doi.org/10.1038/s41598-019-42946-9.

Bird, M.I., O'Grady, D., Ulm, S., 2016. Humans, water, and the colonization of Australia. Proc. Natl. Acad. Sci. Unit. States Am. 113, 11477-11482. https:// doi.org/10.1073/pnas.1608470113.

Blott, S.J., Pye, K., 2001. GRADISTAT: a grain size distribution and statistics package for the analysis of unconsolidated sediments. Earth Surf. Process. Landforms 26, 1237-1248. https://doi.org/10.1002/esp.261.

Bradshaw, C.J.A., Ulm, S., Williams, A.N., Bird, M.I., Roberts, R.G., Jacobs, Z., Laviano, F., Weyrich, L.S., Friedrich, T., Norman, K., Saltre, F., 2019. Minimum founding populations for the first peopling of Sahul. Nat. Ecol. Evol. 3, 1057-1063. https://doi.org/10.1038/s41559-019-0902-6.

Brumm, A., Jensen, G.M., Van den Bergh, G.D., Morwood, M.J., Kurniawan, I., Aziz, F., Storey, M., 2010. Hominins on Flores, Indonesia, by one million years ago. Nature 464, 748-753. https://doi.org/10.1038/nature08844.

Bulmer, S., 1977. Waisted blades and axes: a functional interpretation of some early stone tools from Papua New Guinea. In: Wright, R.V.S. (Ed.), Stone Tools as Cultural Markers: Change, Evolution and Complexity. Humanities Press Inc., New Jersey, pp. 40-59.

Caffrey, M.A., Horn, S.P., 2013. The use of lithium heteropolytungstate in the heavy liquid separation of samples which are sparse in pollen. Palynology 37, $143-150$.

Cernohorsky, W.O., 1972. Marine Shells of the Pacific. Pacific Publications, Sydney.

Chambers, F.M., Beilman, D.W., Yu, Z., 2011. Methods for determining peat humification and for quantifying peat bulk density, organic matter and carbon content for palaeostudies of climate and peatland carbon dynamics. Mires Peat 7, 1-10. http://www.mires-and-peat.net/pages/volumes/map07/map0707.php.

Chappell, J., Polach, H., 1991. Post-glacial sea-level rise from a coral record at Huon Peninsula, Papua New Guinea. Nature 349, 147-149. https://doi.org/10.1038/ 349147a0.

Chynoweth, M., Summerhayes, G.R., Ford, A., Negishi, Y., 2020. Lapita on Wari island: what's the problem? Asian Perspect. 59, 100-116. https://muse.jhu.edu/ article/754062.

Clarkson, C., Jacobs, Z., Marwick, B., Fullagar, R., Wallis, L., Smith, M., Roberts, R.G., Hayes, E., Lowe, K., Carah, X., Florin, S.A., McNeil, J., Cox, D., Arnold, L.J., Hua, Q. Huntley, J., Brand, H.E.A., Manne, T., Fairbairn, A., Shulmeister, J., Lyle, L., Salinas, M., Page, M., Connell, K., Park, G., Norman, K., Murphy, T., Pardoe, C. 2017. Human occupation of northern Australia by 65,000 years ago. Nature 547, 306-310. https://doi.org/10.1038/nature22968.

Cobb, B.J., Lee, L.L., Kaiapranis, R., 2004. PNGplants Database: Plant Collections from Papua New Guinea.

David, B., McNiven, I.J., Leavesley, M., Barker, B., Mandui, H., Richards, T., Skelly, R., 2012. A new ceramic assemblage from Caution Bay, South Coast of Mainland PNG: the linear shell edge-impressed tradition from Bogi 1. J. Pacific Archaeol. 3, 73-89. https://pacificarchaeology.org/index.php/journal/article/view/69.

Davies, H.L., Ives, D.J., 1965. The Geology of Fergusson and Goodenough Islands, Papua. Bureau of Mineral Resources, Geology and Geophysics, Canberra.

de Keyser, F., 1961. Misima Island - Geology and Gold Mineralization. Bureau of Mineral Resources, Geology and Geophysics, Canberra.

Dickinson, W.R., 2003. Impact of mid - Holocene hydro-isostatic highstand in regional sea level on habitability of islands in Pacific Oceania. J. Coast Res. 19, 489-502. www.jstor.org/stable/4299192.

Dickinson, W.R., 2014. Beach ridges as favored locales for human settlement on Pacific Islands. Geoarchaeology 29, 249-267. https://doi.org/10.1002/gea.21476.

Dunn, M., Levinson, S.C., Lindstrom, E., Reesink, G., Terril, A., 2008. Structural phylogeny in historical linguistics: methodological explorations applied in Island Melanesia. Language 84, 710-759. https://www.jstor.org/stable/40071101.

Fagri, K., Iversen, J., 1989. Testbook of Pollen Analysis. John Wiley and Sons, Chichester.

Fink, D., Hotchkis, M., Hua, Q., Jacobsen, G., Smith, A.M., Zoppi, U., Child, D.,
Misfud, C., van der Gaast, H., Williams, A., Williams, M., 2004. The ANTARES AMS facility at ANSTO. Nucl. Instrum. Methods Phys. Res. Sect. B Beam Interact. Mater. Atoms 223-224, 109-115. https://doi.org/10.1016/j.nimb.2004.04.025.

Flannery, T.F., 1995. Mammals of the South-West Pacific and Moluccan Islands Comstock/Cornell, Ithica, NY.

Fredericksen, C., Spriggs, M., Ambrose, W., 1993. Pamwak rockshelter: a Pleistocene site on Manus island, Papua New Guinea. In: Smith, M.A., Spriggs, M., Fankhauser, B. (Eds.), Sahul in Review: Pleistocene Archaeology in Australia, New Guinea and Island Melanesia. The Australian National University, Canberra, pp. 144-152.

Glascock, M.D., Neff, H., 2003. Neutron activation analysis and provenance research in archaeology. Meas. Sci. Technol. 14, 1516-1526. https://doi.org/10.1088/0957$0233 / 14 / 9 / 304$.

Gosden, C., Robertson, N., 1991. Models for Matenkupkum: interpreting a late Pleistocene site from southern new Ireland, Papua New Guinea. In: Allen, J., Gosden, C. (Eds.), Report of the Lapita Homeland Project. Australian National University, Canberra, pp. 20-45.

Green, R.C., 1991. Near and remote Oceania - disestablishing "melanesia" in culture history. In: Pawley, A. (Ed.), Man and a Half: Essays in Pacific Anthropology and Ethnobiology in Honour of Ralph Bulmer. The Polynesian Society, Auckland, pp. 491-502.

Groube, L., 1989. The taming of the rain forests: a model for Late Pleistocene forest exploitation in New Guinea. In: Harris, D.R., Hillman, G.C. (Eds.), Foraging and Farming: the Evolution of Plant Exploitation. Unwin Hyman, London, pp. 292-304.

Groube, L., Chappell, J., Muke, J., Price, D., 1986. A 40,000 year-old human occupation site at Huon Peninsula, Papua New Guinea. Nature 324, 453-455. https:// doi.org/10.1038/324453a0.

Hanebuth, T.J.J., Statteggar, K., Bojanowski, A., 2009. Termination of the last glacial maximum sea-level lowstand: the sunda-shelf data revisited. Global Planet. Change 66, 76-84. https://doi.org/10.1016/j.gloplacha.2008.03.011.

Hawkins, S., O'Connor, S., Maloney, T., Litster, M., Kealy, S., Fenner, J.N., Aplin, K., Boulanger, C., Brockwell, S., Willan, R., Piotto, E., Louys, J., 2017. Oldest human occupation of Wallacea at Laili Cave, Timor-Leste, shows broad-spectrum foraging responses to Late Pleistocene environments. Quat. Sci. Rev. 171, 58-72. https://doi.org/10.1016/j.quascirev.2017.07.008.

Hinton, A., 1975. Guide to Shells of Papua New Guinea. Robert Brown \& Associates Pty. Ltd, Port Moresby.

Hiscock, P., 2008. Archaeology of Ancient Australia. Routledge, Abingdon, Oxon.

Holdaway, S., Stern, N., 2004. A Record in Stone: the Study of Australia's Flaked Stone Artefacts. Museum Victoria, Melbourne.

Hua, Q., Jacobsen, G., Zoppi, U., Lawson, E.M., Williams, A., Smith, A.M. McGann, M.J., 2001. Progress in radiocarbon target preparation at the ANTARES AMS centre. Radiocarbon 43, 275-282. https://doi.org/10.1017/ S003382220003811X

Irwin, G., 1992. The Prehistoric Exploration and Colonisation of the Pacific. Cambridge University Press, Cambridge.

Irwin, G., Shaw, B., McAlister, A., 2019. The origins of the Kula Ring: archaeological and maritime perspectives from the southern Massim and Mailu areas of Papua New Guinea. Archaeol. Ocean. 54, 1-16. https://doi.org/10.1002/arco.5167.

Ishiwa, T., Yokoyama, Y., Miyairi, Y., Obrochta, S., Sasaki, T., Kitamura, A., Suzuki, A. Ikehara, M., Ikehara, K., Kimoto, K., Bourget, J., Matsuzaki, H., 2016. Reappraisal of sea-level lowstand during the last glacial maximum observed in the bonaparte gulf sediments, northwestern Australia. Quat. Int. 397, 373-379. https:// doi.org/10.1016/j.quaint.2015.03.032.

Jones, S.G., Ellis, D.V., 1995. Deep water STD at the Misima gold and silver mine Papua, New Guinea. Mar. Georesour. Geotechnol. 13, 183-200. https://doi.org/ $10.1080 / 10641199509388283$.

Kaplin, P., 1994. Geomorphology, geological structure and genetic types of islands in the southwest pacific. In: Pernetta, J., Manner, H. (Eds.), The Ecosystems of Small Islands in the Southwest Pacific (The Sixth Expedition of the SS 'Calisto') UNEP, Apia, pp. 9-28.

Kealy, S., Louys, J., O'Connor, S., 2016. Islands under the sea: a review of early modern human dispersal routes and migration hypotheses through Wallacea J. I. Coast Archaeol. 11, 364-384. https://doi.org/10.1080/ 15564894.2015.1119218.

Lambeck, K., Chappell, J., 2001. Sea level change through the last glacial cycle. Science 292, 679-686. https://doi.org/10.1126/science.1059549.

Lambeck, K., Rouby, H., Purcell, A., Sun, Y., Sambridge, M., 2014. sea level and global ice volumes from the last glacial maximum to the Holocene. Proc. Natl. Acad. Sci. U.S.A. 111, 15296-15303. https://doi.org/10.1073/pnas.1411762111.

Lampert, R.J., 1981. The Great Kartan Mystery. Australian National University, Canberra.

Lampert, R.J., 1983. Waisted blades in Australia? Record Aust. Mus. 35, 145-151. https://www.austmus.gov.au/Uploads/Journals/17606/314.pdf.

Leavesley, M., 2004. Trees to the Sky: Prehistoric Hunting in New Ireland, Papua New Guinea. Australian National University.

Leavesley, M., 2006. Late Pleistocene complexities in the Bismarck archipelago. In: Lilley, I. (Ed.), Archaeology of Oceania: Australia and the Pacific Islands. Blackwell Publishing, Carlton, Victoria, pp. 189-204.

Leavesley, M., Allen, J., 1998. Dates, disturbance and artefact distributions: another analysis of Buang Merabak, a Pleistocene site on new Ireland, Papua New Guinea. Archaeol. Ocean. 33, 63-68. https://doi.org/10.1002/j.18344453.1998.tb00405.x.

Levinson, S.C., 2008. Landscape, seascape and the ontology of places on Rosse 
Island, Papua New Guinea. Lang. Sci. 30, 256-290. https://doi.org/10.1016/ j.langsci.2006.12.032.

Liep, J., 2009. A Papuan Plutocracy: Ranked Exchange on Rossel Island. Aarhus University Press, Aarhus.

Lyman, R.L., 2008. Quantitative Paleozoology. Cambridge University Press, Cambridge.

Maloney, T., O'Conner, S., Wood, R., Aplin, K., Balme, J., 2018. Carpenters Gap 1: a 47,000 year record of indigenous adaption and innovation. Quat. Sci. Rev. 191 204-228. https://doi.org/10.1016/j.quascirev.2018.05.016.

McNiven, I., David, B., Richards, T., Aplin, K., Asmussen, B., Mialanes, J., Leavesley, M. Faulkner, P., Ulm, S., 2011. New direction in human colonisation of the pacific: Lapita settlement of south coast new Guinea. Aust. Archaeol. 72, 1-6. https: doi.org/10.1080/03122417.2011.11690525.

McNiven, I.J., De Maria, N., Weisler, M.I., Lewis, T., 2014. Darumbal voyaging: intensifying use of central Queensland's Shoalwater Bay islands over the past 5000 years. Archaeol. Ocean. 49, 2-42. https://doi.org/10.1002/arco.5016.

Monteleone, B.D., Baldwin, S.L., Webb, L.E., Fitzgerald, P.G., Grove, M., Schmitt, A.K., 2007. Late miocene-pliocene eclogite facies metamorphism, D'entrecasteaux islands, SE Papua New Guinea. J. Metamorph. Geol. 25, 245-265. https:// doi.org/10.1111/j.1525-1314.2006.00685.x.

Munsell, C., 2000. Munsell Soil Color Charts. Gretagmacbeth, New Windsor.

Negishi, Y., Ono, R., 2009. Kasasinabwana shell midden: the prehistoric ceramic sequence of Wari Island in the Massim, eastern Papua New Guinea. People Cult. Ocean. 25, 23-52.

O'Connell, J.F., Allen, J., 2007. Pre-LGM Sahul (Australia-New Guinea) and the archaeology of early modern humans. In: Millars, P., Boyle, K., Bar-Yosef, O. Stringer $C$ (Eds.), Rethinking the Human Revolution: New Behavioural and Biological Perspectives on the Origin and Dispersal of Modern Humans McDonald Institute for Archaeology Research, Cambridge, pp. 395-410.

O'Connor, S., Aplin, K., Szabo, K., Pasveer, J., Veth, P., Spriggs, M., 2006. Liang Lemdubu: a Pleistocene cave site in the Aru islands. In: O'Connor, S., Spriggs, M. Veth, P. (Eds.), The Archaeology of the Aru Islands, Eastern Indonesia. ANU EPress, Canberra, pp. 171-204.

O’Connor, S., Barham, A.J., Aplin, K., Dobney, K., Fairbairn, A., Richards, M., 2011. The power of paradigms: examining the evidential basis for Early to Mid-Holocene pigs and pottery in Melanesia. J. Pacific Archaeol. 2, 1-25. https://www. pacificarchaeology.org/index.php/journal/article/view/56.

O'Connor, S., Louys, J., Kealy, S., Samper Carro, S.C., 2017. Hominin dispersal and settlement east of Huxley's line: the role of sea level changes, island size, and subsistence behavior. Curr. Anthropol. 58, S567-S582. https://doi.org/10.1086/ 694252.

O’Connor, S., Mahirta, Kealy, S., Boulanger, C., Maloney, T., Hawkins, S., Langley, M.C., Kaharudin, H.A.F., Suniarti, L., Husni, M., Ririmasse, M., Tanudirjo, D Wattimena, L., Handoko, W., Alifah, Louys, J., 2019. Kisar and the archaeology of small islands in the Wallacean Archipelago. J. I. Coast Archaeol. 14, 198-225. https://doi.org/10.1080/15564894.2018.1443171.

O'Connor, S., Veth, P., 2006. Revisiting the past: changing interpretations of Pleistocene settlement subsistence and demography in northern Australia. In: Lilley, I. (Ed.), Archaeology of Oceania. Blackwell Publishing, Victoria, pp. 31-48.

Paijmans, K., 1976. New Guinea Vegetation. The Australian National University Canberra.

Pavlides, C., 2004. From misisil cave to eliva hamlet: rediscovering the Pleistocene in interior west new Britain. Record Aust. Mus. 29, 97-108. https://journals. australianmuseum.net.au/pavlides-2004-rec-aust-mus-suppl-29-97108/.

Pedro, N., Brucato, N., Fernandes, V., Andre, M., Saag, L., Pomat, W., Besse, C. Boland, A., Deleuze, J., Clarkson, C., Sudoyo, H., Metspalu, M., Stoneking, M., Cox, M.P., Leavesley, M., Pereira, L., Ricaut, F., 2020. Papuan mitochondrial genomes and the settlement of Sahul. J. Hum. Genet. 1-13. https://doi.org 10.1038/s10038-020-0781-3.

Petchey, F., Anderson, A., Zondervan, A., Ulm, S., Higg, A., 2008. New marine $\Delta R$ values for the South Pacific subtropical gyre region. Radiocarbon 50, 373-397. https://doiorg/10,1017/S0033822200053509.

Petchey, F., Ulm, S., 2012. Marine reservoir variation in the Bismarck Region: an evaluation of spatial and temporal change in $\Delta \mathrm{R}$ and $\mathrm{R}$ over the last 3000 years. Radiocarbon 54, 45-58. https://doi.org/10.2458/azu_js_rc.v54i1.13050.

Potts, P.J., Tindle, A.G., Webb, P.C., 1992. Geochemical Reference Material Compositions. Whittles Publishing, Caithness.

Ramsey, C.B., 2009. Bayesian analysis of radiocarbon dates. Radiocarbon 51, 337-360. https://doi.org/101017/S0033822200033865.

Reeves, J.M., Bostock, H.C., Ayliffe, L.K., Barrows, T.T., De Deckker, P., Devriendt, L.S. Dunbar, G.B., Drysdale, R.N., Fitzsimmons, K.E., Gagan, M.K., Griffiths, M.L. Haberle, S., Jansen, J.D., Krause, C., Lewis, S., McGregor, H.V., Mooney, S.D. Moss, P., Nanson, G.C., Purcell, A., van der Kaars, S., 2013. Palaeoenvironmental change in tropical Australasia over the last 30,000 years - a synthesis by the OZ-INTIMATE group. Quat. Sci. Rev. 74, 97-114. https://doi.org/10.1016 j.quascirev.2012.11.027.

Reimer, P.J., Bard, E., Bayliss, A., Beck, J.W., Blackwell, P.G., Ramsey, C.B., Buck, C.E., Cheng, H., Edwards, R.L., Friedrich, M., Grootes, P.M., Guilderson, T.P. Haflidason, H., Hajdas, I., Hatte, C., Heaton, T.J., Hoffmann, D.L., Hogg, A.G., Hughen, K.A., Kaiser, K.F., Kromer, B., Manning, S.W., Niu, M., Reimer, R.W. Richards, D.A., Scott, E.M., Southon, J.R., Staff, R.A., Turney, C.S.M., van de Plicht, J., 2013. IntCal13 and Marine13 radiocarbon age calibration curves 050,000 years cal BP. Radiocarbon 55, 1869-1887. https://doi.org/10.2458/azu js_rc.55.16947.

Rosenfeld, A., 1997. Excavation at Buang Merabak, central new Ireland. Bull. Indo-
Pacific Prehistory Assoc. 16, 213-224. https://doi.org/10.7152/ bippa.v16i0.11662.

Ross, M.D., 1988. Proto Oceanic and the Austronesian Languages of Western Melanesia. Pacific Linguistics, Canberra.

Rowland, M.J., Wright, S., Baker, S., 2015. The timing and use of offshore islands in the great barrier reef marine Province, queensland. Quat. Int. 385, 154-165. https://doi.org/10.1016/j.quaint.2015.01.025.

Samper Carro, S.C., O'Connor, S., Louys, J., Hawkins, S., Mahirta, M., 2016. Human maritime subsistence strategies in the lesser sunda islands during the terminal pleistocene-early Holocene: new evidence from alor, Indonesia. Quat. Int. 416, 64-79. https://doi.org/10.1016/j.quaint.2015.07.068.

Shaw, B., 2015. The Archaeology of Rossel Island, Massim, Papua New Guinea: towards a Prehistory of the Louisiade Archipelago, ume 1. Australian National University, Canberra.

Shaw, B., 2016a. The late prehistoric introduction of pottery to Rossel Island, Louisiade Archipelago, Papua New Guinea: insights into local social organisation and regional exchange in the Massim. Archaeol. Ocean. 51, 61-72. https:// doi.org/10.1002/arco.5104.

Shaw, B., 2016b. The Massim region of Papua New Guinea: a review and proposed chronology. J. Pacific Archaeol. 7, 106-125. https://pacificarchaeology.org/index. $\mathrm{php} /$ journal/article/view/172

Shaw, B., 2017. Late Pleistocene colonisation of the eastern New Guinea islands? The potential implications of robust waisted stone tool finds from Rossel Island on the long term settlement dynamics in the Massim region. J. Pacific Archaeol. 8, 1-16. https://pacificarchaeology.org/index.php/journal/article/view/234.

Shaw, B., 2019. Archaeology of the Massim island region, Papua New Guinea. In: Smith, C. (Ed.), Encyclopedia of Global Archaeology. Springer Reference, New York, pp. 1-15. https://doi.org/10.1007/978-3-319-51726-1_3444-1.

Shaw, B., Coxe, S., Kewibu, V., Haro, J., Hull, E., Hawkins, S., 2020a. 2500-year cultural sequence in the Louisiade Archipelago (Massim region) of eastern Papua New Guinea reflects adaptive strategies to remote islands since Lapita settlement. Holocene 1-16. https://doi.org/10.1177/0959683620908641.

Shaw, B., Field, J., Summerhayes, G., Coxe, S., Coster, A.C.F., Ford, A., Haro, J., Arifeae, H., Hull, E., Jacobsen, G., Fullagar, R., Hayes, E., Kealhofer, L., 2020b. Emergence of a neolithic in highland new Guinea by 5000-4000 years ago. Sci. Adv. https://doi.org/10.1126/sciadv.aay4573 eaay4573.

Sheppard, P.J., Chiu, S., Walter, R., 2015. Re-dating Lapita movement into remote Oceania. J. Pacific Archaeol. 6, 26-36. https://pacificarchaeology.org/index.php/ journal/article/view/152.

Sheppard, P.J., Trichereau, B., Milicich, C., 2010. Pacific obsidian sourcing by portable XRF. Archaeol. Ocean. 45, 21-30. https://doi.org/10.1002/j.18344453.2010.tb00074.x.

Sim, R., Wallis, L., 2008. Northern Australian offshore island use during the Holocene: the archaeology of vanderlin island, sir edward pellew group, gulf of Carpentaria. Aust. Archaeol. 67, 95-106. https://doi.org/10.1080/ 03122417.2008.11681882.

Slack, M., Fillios, M., Fullagar, R., 2009. Aboriginal settlement during the LGM at brockman, pilbara region, western Australia. Archaeol. Ocean. 44, 32-39. https://doi.org/10.1002/j.1834-4453.2009.tb00066.x.

Smith, A., Allen, J., 1999. Pleistocene shell technologies: evidence from island melanesia. In: Hall, J., McNiven, I.J. (Eds.), Australian Coastal Archaeology. Australian National University, Canberra, pp. 291-297.

Smith, I.E., Pieters, P.E., 1969. The Geology of the Louisiade Archipelago, T.P.N.G., Excluding Misima Island. Bureau of Mineral Resources. Geology and Geophysics, Port Moresby.

Smith, I.E., Pieters, P.E., 1973. The geology of the deboyne island group, southeastern Papua. BMR 139, 71-74.

Smith, M., 2013. The Archaeology of Australia's Deserts. Cambridge University Press, New York.

Specht, J., Gosden, C., 2019. New dates for the makekur (FOH) Lapita pottery site, arawe islands, new Britain, Papua New Guinea. In: Bedford, S., Spriggs, M. (Eds.) Debating Lapita: Distribution, Chronology, Society and Subsistence. ANU Press, Canberra, pp. 168-202.

Sperazza, M., Moore, J.N., Hendrix, M.S., 2004. High-resolution particle size analysis of naturally occurring very fine-grained sediment through laser diffractometry. J. Sediment. Res. 74, 736-743. https://doi.org/10.1306/031104740736.

Stockmarr, J., 1971. Tablets with spores used in absolute pollen analysis. Pollen Spores 13, 615-621.

Summerhayes, G., Field, J., Shaw, B., Gaffney, D., 2017. The archaeology of forest exploitation and change in the tropics during the Pleistocene: the case of Northern Sahul (Pleistocene New Guinea). Quat. Int. 448, 14-30. https:// doi.org/10.1016/j.quaint.2016.04.023.

Summerhayes, G., Leavesley, M., Fairbairn, A., Mandui, H., Field, J., Ford, A. Fullagar, R., 2010a. Human adaptation and plant use in highland new Guinea 49,000 to 44,000 Years ago. Science 330, 78-81. https://doi.org/10.1126/ science.1193130.

Summerhayes, G.R., 2007. The rise and transformation of Lapita in the Bismarck archipelago. In: Chui, S., Sand, C. (Eds.), From Southeast Asia to the Pacific: Archaeological Perspectives on the Austronesian Expansion and the Lapita Cultural Complex. Academic Sinica, Taipei, pp. 129-172.

Summerhayes, G.R., Allen, J., 1993. The transport of mopir obsidian to late Pleistocene new Ireland. Archaeol. Ocean. 28, 144-148. https://doi.org/10.1002/j.18344453.1993.tb00305.x.

Summerhayes, G.R., Matisoo-Smith, E., Mandui, H., Allen, J., Specht, J., Hogg, N., McPherson, S., 2010b. Tamuarawai (EQS): an early Lapita site on emirau, new 
Ireland, PNG. J. Pacific Archaeol. 1, 62-75. https://pacificarchaeology.org/index. $\mathrm{php} /$ journal/article/view/10.

Swadling, P., 2016. Mid Holocene social networks in far eastern New Guinea. J. Pacific Archaeol. 7, 7-19. https://pacificarchaeology.org/index.php/journal/ article/view/179.

Taylor, J.M., Calaby, J.H., Van Deusen, H.M., 1982. A revision of the genus Rattus (Rodentia, Muridae) in the New Guinea region. Bull. Am. Mus. Nat. Hist. 173, 177-336. http://hdl.handle.net/2246/571.

Torrence, R., Kelloway, S., White, P., 2013. Stemmed tools, social interaction, and voyaging in early-mid Holocene Papua New Guinea. J. I. Coast Archaeol. 8, 278-310. https://doi.org/10.1080/15564894.2012.761300.

Torrence, R., Swadling, P., 2008. Social networks and the spread of Lapita. Antiquity 82, 600-616. https://doi.org/10.1017/S0003598X00097258.

Ulm, S., 2011. Coastal foragers on southern shores: marine resource use in northeast Australia since the Late Pleistocene. In: Bicho, N., Haws, J., Davis, L. (Eds.), Trekking the Shore. Interdisciplinary Contributions to Archaeology. Springer, New York, pp. 441-461.

van den Bergh, G.D., Li, B., Brumm, A., Grun, R., Yurnaldi, D., Moore, M.W., Kurniawan, I., Setiwan, R., Aziz, F., Roberts, R.G., Suyono, Storey, M., Setiabudi, E., Morwood, M.J., 2016. Earliest hominin occupation of Sulawesi, Indonesia. Nature 529, 208-211. https://doi.org/10.1038/nature16448.

van Oven, M., Brauer, S., Choi, Y., Ensing, J., Schiefenhovel, W., Stoneking, M. Kayser, M., 2014. Human genetics of the kula ring: Y-chromosome and mitochondrial DNA variation in the Massim of Papua New Guinea. Eur. J. Hum. Genet. 1-11 https://doi.org/10.1038/ejhg.2014.38.

Veth, P., 1993. Islands in the Interior: the Dynamics of Prehistoric Adaptations within the Arid Zone of Australia. Berghahn Books, Ann Arbor.

Veth, P., Ward, I., Manne, T., Ulm, S., Ditchfield, K., Dortch, J., Hook, F., Petchey, F., Hogg, A., Questiaux, D., Demuro, M., Arnold, L., Spooner, N., Levchenko, V., Skippington, J., Byrne, C., Basgall, M., Zeanah, D., Belton, D., Helmholz, P. Bajkan, S., Bailey, R., Placzek, C., Kendrick, P., 2017. Early human occupation of a maritime desert, Barrow Island, North-West Australia. Quat. Sci. Rev. 168,
19-29. https://doi.org/10.1016/j.quascirev.2017.05.002

Webster, J.M., Braga, J.C., Humblet, M., Potts, D.C., Iryu, Y., Yokoyama, Y., Fujita, K. Bourillot, R., Esat, T.M., Fallon, S., Thompson, W.G., Thomas, A.L., Kan, H., McGregor, H.V., Hinestrosa, G., Obrochta, S.P., Lougheed, B.C., 2018. Response of the Great Barrier Reef to sea-level and environmental changes over the past 30,000 years. Nat. Geosci. 11, 426-432. https://doi.org/10.1038/s41561-0180127-3.

Wells, F., Kinch, J.P., 2003. Molluscs of Milne Bay Province, Papua New Guinea. In: Allen, G.R., Kinch, J.P., McKenna, S.A., Seeto, P. (Eds.), A Rapid Marine Diversity Assessment of Milne Bay Province, Papua New Guinea - Survey II (2000). Conservation International, Washington, DC, pp. 39-45.

Wickler, S., Spriggs, M., 1988. Pleistocene human occupation of the Solomon Islands Melanesia. Antiquity 62, 703-706. https://doi.org/10.1017/ S0003598X00075104.

Wikramanayake, E., Dinerstein, E., Loucks, C.J., Olson, D.M., Morrison, J. Lamoreux, J., McKnight, M., Hedao, P., 2002. Terrestrial Ecoregions of the IndoPacific: A Conservation Assessment. Island Press, Washington.

Will, M., Kandel, A.W., Conrad, N.J., 2019. Midden or molehill: the role of coastal adaptations in human evolution and dispersal. J. World PreHistory 32, 33-72. https://doi.org/10.1007/s10963-018-09127-4.

Williams, A., Ulm, S., Cook, A.R., Langley, M.C., Collard, M., 2013. Human refugia in Australia during the Last Glacial Maximum and Terminal Pleistocene: a geospatial analysis of the 25-12 ka Australian archaeological record. J. Archaeol. Sci. 40, 4612-4625. https://doi.org/10.1016/j.jas.2013.06.015.

Williams, A.N., Veth, P., Steffen, W., Ulm, S., Turney, C.S.M., Reeves, J.M., Phipps, S. Smith, M., 2015. A continental narrative: human settlement patterns and Australian climate change over the last 35,000 years. Quat. Sci. Rev.123, 91-112. https://doi.org/10.1016/j.quascirev.2015.06.018.

Woodroffe, C.D., Kennedy, D.M., Hopley, D., Rasmussen, C.E., Smithers, S.G., 2000. Holocene reef growth in torres strait. Mar. Geol. 170, 331-346. https://doi.org/ 10.1016/S0025-3227(00)00094-3. 